\title{
Regulation of M Current by Intracellular Calcium in Bullfrog Sympathetic Ganglion Neurons
}

\author{
Shan Ping Yu, ${ }^{a}$ Donald M. O'Malley, and Paul R. Adams \\ Howard Hughes Medical Institute, Department of Neurobiology and Behavior, State University of New York at Stony \\ Brook, Stony Brook, New York 11794-5230
}

Regulation of $M$ current $\left(I_{M}\right)$ by intracellular free calcium was studied in dissociated bullfrog sympathetic ganglion $B$ cells using whole-cell recording, intracellular perfusion, and confocal calcium imaging. BAPTA $(20 \mathrm{~mm})$ and appropriate amounts of calcium were added to pipette solutions to clamp calcium at different levels. A high concentration of BAPTA itself mildly inhibited $I_{M}$. Intracellular perfusion effectively controlled cellular free calcium; this was confirmed by confocal imaging with the calcium indicator fluo-3. In a calciumfree environment (no calcium added to either side of the cell membrane), average $I_{M}$ was 166 pA. Raising intracellular free calcium to $60 \mathrm{nM}$ or higher reversibly enhanced $I_{M}$ by more than $100 \%$. The maximum $M$ conductance doubled upon raising calcium from 0 to $120 \mathrm{nM}$, and was accompanied by a $-11 \mathrm{mV}$ shift of the half-activation voltage. The kinetics of the closing and reopening relaxations of $I_{m}$ were also altered by raising calcium. Enhancement of $I_{M}$ by calcium required ATP in the pipette. TEA (5 $\mathrm{mM}$ ) and $d$-tubocurarine (d-TC; $100 \mu \mathrm{M}$ ) did not alter the calcium effect, indicating that it was the $M$ current being modulated and not other $K^{+}$ currents. High calcium (450 nM) reduced $I_{M}$. The up- and downregulation of $I_{\mathrm{M}}$ paralleled the increases and decreases of fluorescence intensity observed via calcium imaging. Changing extracellular calcium had no significant effect on $I_{\mathrm{M}}$ or cellular fluorescence.

The role of calcium in muscarinic and peptidergic modulation of $I_{\mathrm{M}}$ was also explored. Muscarine $(1$ or $10 \mu \mathrm{M})$ inhibited $I_{M}$ less at zero calcium than at higher calcium. Nearly complete suppression occurred with $120 \mathrm{nM}$ calcium in the presence of $20 \mathrm{~mm}$ BAPTA. $I_{M}$ overrecovered upon washout of muscarine at $120 \mathrm{nM}$ calcium, while little overrecovery of $I_{\mathrm{M}}$ developed at zero calcium. Similar effects were observed at zero and $120 \mathrm{nM}$ calcium when using the peptide LHRH to inhibit $I_{\mathrm{M}}$. We conclude that the absolute level of free calcium determines the size of $I_{M}$, and that a minimum sustained level of calcium is required both for optimal suppression of $I_{m}$ by muscarine and for overrecovery. While our data

Received Jan. 27, 1993; revised Nov. 8, 1993; accepted Dec. 21, 1993.

Wc cxpress gratitude to Dr. A. Villarroel for computer programming and to Mr. B. J. Burbach for excellent technical support. We thank Dr. N. V. Marrion and Dr. W. Van der Kloot for their comments on the manuscript.

Correspondence should be addressed to Dr. Paul R. Adams, Howard Hughes Medical Institute, Department of Neurobiology and Behavior, SUNY at Stony Brook, Stony Brook, NY 11794-5230.

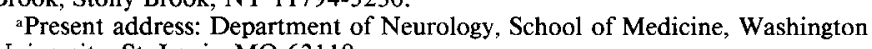
University, St. Louis, MO 63110.

Copyright (C) 1994 Society for Neuroscience $0270-6474 / 94 / 143487-13 \$ 05.00 / 0$ suggest that resting calcium levels play a permissive role in muscarinic suppression, an additional role for agonist-induced calcium increases cannot be ruled out.

The M current $\left(I_{\mathrm{M}}\right)$, a voltage- and time-dependent potassium current, was identified in bullfrog sympathetic neurons (Brown and Adams, 1980; Adams et al., 1982a) and has been demonstrated in central and peripheral neurons of a variety of other vertebrate species (reviewed in Brown, 1988). Activation of $I_{\mathrm{M}}$ drives the membrane potential back toward $E_{K}$, profoundly diminishing cell excitability (Adams and Brown, 1982; Adams et al., 1982b). Muscarine, luteinizing hormone-releasing hormone (LHRH), and other neurotransmitters modulate $I_{\mathrm{M}}$ in two ways: first, they suppress the current; second, after washout of the agonist, $I_{\mathrm{M}}$ is transiently enhanced. This second response is called "overrecovery" (Pfaffinger, 1988). Very high concentrations of agonist also cause desensitization of muscarinic ACh rcceptors (Bosma et al., 1990); this was not investigated here.

$I_{\mathrm{M}}$ was initially characterized as being " $\mathrm{Ca}^{2+}$ independent" in terms of not requiring $\mathrm{Ca}^{2+}$ influx for its activation (Adams et al., 1982b). $I_{\mathrm{M}}$ in both bullfrog (Adams et al., 1982b) and rat (Marrion et al., 1989) sympathetic neurons persists when $\mathrm{Ca}^{2+}$ entry is prevented either by removing $\mathrm{Ca}^{2+}$ from the external medium or by using selective $\mathrm{Ca}^{2+}$ channel blockers. In bullfrog sympathelic neurons, $I_{\mathrm{M}}$ was not changed by intracellular iontophoresis of $\mathrm{Ca}^{2+}$ (Adams et al., 1982b). However, a transient $\left[\mathrm{Ca}^{2+}\right]_{i}$ increase is observed during $I_{\mathrm{M}}$ suppression by muscarine or by LHRH (Pfaffinger et al., 1988; Marrion et al., 1991), raising the possibility of a relationship between $\mathrm{Ca}^{2+}$ and $I_{\mathrm{M}}$.

In bullfrog sympathetic neurons, cobalt only slightly suppressed $I_{\mathrm{M}}$ in the presence of $2 \mathrm{mM} \mathrm{Ca}^{2+}$ (Adams et al., 1982b). However, $I_{\mathrm{M}}$ was reduced by $90 \%$ when $\mathrm{Ca}^{2+}$ was substituted by cobalt or other divalent cations (Tokimasa and Akasu, 1990a). The maximum $\mathrm{M}$ conductance was reduced by $60 \%$ when $\mathrm{Ca}^{2+}$ was removed from the superfusate. It was therefore suggested that extracellular $\mathrm{Ca}^{2+}$ is required for $\mathrm{M}$ channel function (Tokimasa and Akasu, 1990a).

Some investigators have suggested that $\mathrm{Ca}^{2+}$ may be a second messenger regulating $I_{\mathrm{M}}$. Stimulating $\mathrm{Ca}^{2+}$ release from intracellular stores by applying caffeine to bullfrog sympathetic neurons evokes a component of $\mathrm{K}^{+}$current whose voltage and $\mathrm{ACh}$ sensitivity resembles that of $I_{\mathrm{M}}$ (Koketsu et al., 1982). On the other hand, caffeine was also reported to block $I_{\mathrm{M}}$ in these cells (Pfaffinger et al., 1988; Akaike and Sadoshima, 1989). When attempts were made to increase intracellular $\mathrm{Ca}^{2+}$ by membrane depolarization, no obvious effects on $I_{\mathrm{M}}$ were noticed (Pfaffinger et al., 1988). However, the increase in intracellular $\mathrm{Ca}^{2+}$ pro- 
duced by the massive entry of $\mathrm{Ca}^{2+}$ during a calcium spike inhibited $I_{\mathrm{M}}$ (Tokimasa, 1985).

Inositol trisphosphate (IP $)_{3}$ was injected intracellularly to stimulate $\mathrm{Ca}^{2+}$ release from internal stores, but produced no obvious effect on $I_{\mathrm{M}}$ in frog sympathetic ganglion cells (Brown and Adams, 1987) and NG108-15 cells (Higashida and Brown, 1986; Brown and Higashida, 1988). Nevertheless, a high concentration of $\mathrm{IP}_{3}(20-60 \mathrm{~mm}$ in the intracellular recording electrode) blocked $I_{\mathrm{M}}$ in hippocampal CAl cells (Dutar and Nicoll, 1988). Prcvious work from our laboratory (Marrion ct al., 1991) showed that small increases in $\left[\mathrm{Ca}^{2+}\right]_{i}$ produced by photolysis of the "caged" $\mathrm{Ca}^{2+}$ chelator nitr- 5 or by evoking action potentials augmented $I_{\mathrm{M}}$, while larger increases produced by repeated illumination inhibited $I_{\mathrm{M}}$.

Evidence concerning the involvement of $\mathrm{Ca}^{2+}$ in muscarinic regulation of $I_{\mathrm{M}}$ is equally contradictory. Suppression of $I_{\mathrm{M}}$ by muscarine can be reduced by dialyzing the cell with concentrations of BAPTA high enough to reduce resting free calcium. One interpretation was that a certain minimum concentration of intracellular free $\mathrm{Ca}^{2+}\left(\left[\mathrm{Ca}^{2+}\right]_{i}\right)$ is required for the coupling of muscarinic receptors to $\mathbf{M}$ channels (Beech et al., 1991). Alternatively, a transient rise in $\left[\mathrm{Ca}^{2+}\right]_{i}$ is associated with muscarinic suppression (Kirkwood et al., 1991). Muscarine and other agonists that suppress $I_{\mathrm{M}}$ elicit phosphatidylinositol (PI) turnover and produce $\mathrm{Ca}^{2+}$ transients. Kirkwood et al. therefore proposed that it is this rise in calcium that mediates agonistinduced suppression of $I_{\mathrm{M}}$. In contrast, other investigators have reported that elevating $\left[\mathrm{Ca}^{2+}\right]_{i}$ by membrane depolarization or manipulating $\left[\mathrm{Ca}^{2+}\right]_{i}$ by adding BAPTA did not affect the actions of agonists on $I_{\mathrm{M}}$, and it was therefore argued that $\left[\mathrm{Ca}^{2+}\right]_{i}$ was not relevant to suppression of $I_{\mathrm{M}}$ (Pfaffinger et al., 1988; Marrion et al., 1991). The mechanisms by which $I_{M}$ is modulated by muscarine and other agonists are still obscure. Study of these mechanisms and their regulation is important for understanding the control of neuronal excitability.

Previous studies of the relationship between calcium and $I_{\mathrm{M}}$ did not set $\left[\mathrm{Ca}^{2+}\right]_{i}$ at well-defined levels. In the present study, whole-cell recordings were carried out in a configuration that allowed successive perfusions of individual cells with different internal solutions. The free $\mathrm{Ca}^{2+}$ in the pipette solutions and hence the cytoplasmic free $\mathrm{Ca}^{2+}$ could therefore be clamped at different levels. This allowed a direct assessment of the relevance of $\left[\mathrm{Ca}^{2+}\right]_{i}$ for $I_{\mathrm{M}}$ modulation. Confocal imaging was used to verify the effectiveness of the manipulation of intracellular free calcium. A close correlation between $\left[\mathrm{Ca}^{2+}\right]_{i}$ and $I_{\mathrm{M}}$ was revealed in this study. The muscarinic responses (suppression and overrecovery) of $I_{\mathrm{M}}$ were also affected by $\left[\mathrm{Ca}^{2+}\right]_{i}$.

A portion of this work has been published previously in preliminary form (Yu et al., 1991; Yu and Adams, 1992).

\section{Materials and Methods}

Experimental preparation. Experiments were done on B cells from the lumbar VIIIth, IXth, and Xth sympathetic ganglia of the bullfrog, Rana catesbeiana. The isolation and dissociation of the sympathetic ganglia were described previously (Kuffler and Sejnowski, 1983). Briefly, the ganglia were dissected and cut into small pieces that were then incubated for $30 \mathrm{~min}$ at $37^{\circ} \mathrm{C}$ in Ringer solution containing $1 \mathrm{mg} / \mathrm{ml}$ collagenase (Worthington, Freehold, NJ) and $5 \mathrm{mg} / \mathrm{ml}$ dispase (Boehringer Mannheim, Germany). The ganglia were then mechanically disrupted by repeatedly passing the tissue through the tip of a fire-polished Pasteur pipette. Complete dissociation of the ganglion cells was achieved after a second digestion for $30 \mathrm{~min}$ at $37^{\circ} \mathrm{C}$ in enzyme solution with $5 \mathrm{mg}$ $\mathrm{ml}$ dispase, followed by further mechanical disruption. After washing the cells three times in Ringer solution, the isolated cells were plated in plastic Petri dishes, and stored at $8^{\circ} \mathrm{C}$ in L-15 medium containing $10 \%$ fetal calf serum, $0.2 \%$ glucose, and $1 \mathrm{~mm} \mathrm{CaCl}_{2}$ (GIBCO, Gaithersburg, $\mathrm{MD})$. Usually the dissociated cells attached to the bottom of the dish, which was used as the experimental chamber. The dissociated cells were roughly spherical and devoid of visible processes. The cells were used within the next $10 \mathrm{~d}$; there was no detectable deterioration.

Whole-cell recording. Membrane currents were recorded using the whole-cell configuration of the patch clamp (Hamill et al., 1981). The tip resistance of the firc-polished clectrode was 1-2 $\mathrm{M} \Omega$. Whole-cell voltage clamp was performed using an Axoclamp 2A amplifier (Axon Instruments) in the discontinuous mode. For $\mathrm{Na}^{+}$current recording the sampling rate on the amplifier was $20 \mathrm{kHz}$. For recording $\mathrm{K}^{+}$currents, sampling rates of $7-15 \mathrm{kHz}$ were used. Voltage and current were displayed on a storage oscilloscope (Tektronix Inc.) and a computer monitor. They were simultaneously recorded by a data acquisition/analysis program written in ASYST language (ASYST 1.53, Macmillan Software Company, NY) on an IBM-compatible computer (Compaq Deskpro 286) and a chart recorder (Gould RS 3400). A second oscilloscope was used to monitor the headstage voltage transient decay continuously to ensure sufficient capacity compensation.

Dissociated neurons were visualized using inverted phase-contrast microscopy (Zeiss, Germany). B-type spherical neurons with diameters of 40-60 $\mu \mathrm{m}$ were chosen for recordings. After gigascal formation (10$40 \mathrm{G} \Omega$ seal resistance) and establishment of the whole-cell configuration, the cells were first clamped at $-60 \mathrm{mV}$ to check the membrane input resistance. Neurons were used only if they had input resistances over $80 \mathrm{M} \Omega$; usually the input resistance was more than $100 \mathrm{M} \Omega$.

To record $\mathrm{Na}^{+}$currents, electrodes were filled with the following solution (in mM): $\mathrm{CsCl}, 110$ or 10; $\mathrm{NaCl}, 5$ or 105 ; HEPES, 5; EGTA, 1; TEA, 3. The external solution for $\mathrm{Na}^{+}$current recording was (in mM) $\mathrm{NaCl}, 115 ; \mathrm{TEA}, 5 ; \mathrm{MnCl}_{2}$; and Tris 2.5. To record $\mathrm{M}$ current, a modified Ringer solution contained (in $\mathrm{mM}$ ) $\mathrm{NaCl}, 115 ; \mathrm{KCl}, 2.5 ; \mathrm{MnCl}_{2}$, 2.0; HEPES, 10.0; EGTA [ethylene glycol bis-( $\beta$-aminoethylether)$N, N, N^{\prime}, N^{\prime}$-tetraacetic acid], $0.5 ; \mathrm{D}$-glucose 5.0 ; and no added $\mathrm{Ca}^{2+}$. $\mathrm{Mn}^{2+}$ was used as a substitute divalent cation to maintain membrane surface potentials and to prevent any possible $\mathrm{Ca}^{2+}$ influx. Patch-clamp electrodes used for normal $I_{\mathrm{M}}$ recording were filled with the following solution (in mM): $\mathrm{K}$-aspartate, $60 ; \mathrm{KCl}, 50 ; \mathrm{MgCl}_{2}, 1.5$; HEPES, 10; BAPTA [1,2-bis(2-aminophenoxy)ethane- $N, N, N^{\prime}, N^{\prime}$-tetraacetic acid], $20 ; \mathrm{Na}_{2}-\mathrm{ATP}, 1.5$; and $\mathrm{CaCl}_{2}, 8.47$. This solution was calculated to contain $120 \mathrm{nM}$ free $\mathrm{Ca}^{2+}$ (see below), a value in the range of physiological $\mathrm{Ca}^{2+}$ levels found in bullfrog ganglion cells (Pfaffinger et al., 1988; Marrion et al., 1991). The pH of intra- or extracellular solutions was 7.2 , adjusted by Tris base or $\mathrm{HCl}$. Recordings were made at room temperature $\left(21-23^{\circ} \mathrm{C}\right)$. Extracellular solutions routinely flowed at the rate of $1 \mathrm{ml} / \mathrm{min}$. The dish contained $1.5 \mathrm{ml}$ of solution, which could be replaced completely in less than $20 \mathrm{sec}$ by speeding up the flow rate. Data stored on computer or chart paper were later measured by the ASYST 1.53 program or by ruler. The Student's $t$ test was used for statistical tests. Mean values are given with SEM.

The $K_{D}$ for BAPTA originally published by Tsien (1980), $110 \mathrm{nM}$, had been determined for a $200 \mathrm{mOsm}$ solution. This value was corrected to account for the increased osmolarity of bullfrog Ringer (about 270 mOsm) based on the study by Harrison and Bers (1987). The corrected value, $160 \mathrm{~nm}$, provided the best fit between calculated values of free calcium (using an iterative program written in the ASYST program language by Alvaro Villaroel and based on the methods of Fabiato (1988) and experimentally measured fluorescence levels of fluo-3 in an intracellular solution. The ASYST program takes into account binding of multiple metals (e.g., $\mathrm{Mg}^{2+}$ and $\mathrm{Mn}^{2+}$ ) and multiple buffers (e.g., ATP, fluo-3). Alternatively, use of Harrison and Bers' $K_{D}$ for BAPTA, 212 $\mathrm{nM}$, under our control conditions, would predict a free calcium level of $160 \mathrm{~nm}$ rather than $120 \mathrm{nM}$, but use of this $K_{D}$ did not fit the experimental calibration curve as well as the corrected value of Tsien.

Intracellular perfusion. Control of intracellular ions was achieved by an intrapipette perfusion procedure and cellular dialysis. It is referred to here as intracellular perfusion (Lopez, 1992). Several technical modifications were made as follows. A modified electrode holder (A058-C, E. W. Wright) with two outlets was used. An internal perfusion tube of about $200 \mu \mathrm{m}$ in external diameter was placed close to the tip down the inside of the recording electrode. Electrodes were pulled from Microcaps micropipettes (Drummond Scientific Company, Broomall, PA) on a Flaming Brown Micropipette puller (P-80 PC, Sutter Instrument Co.) Five or six pull stages were programmed to control more accurately the shape of the electrode tip. The electrode shank was made as short as 

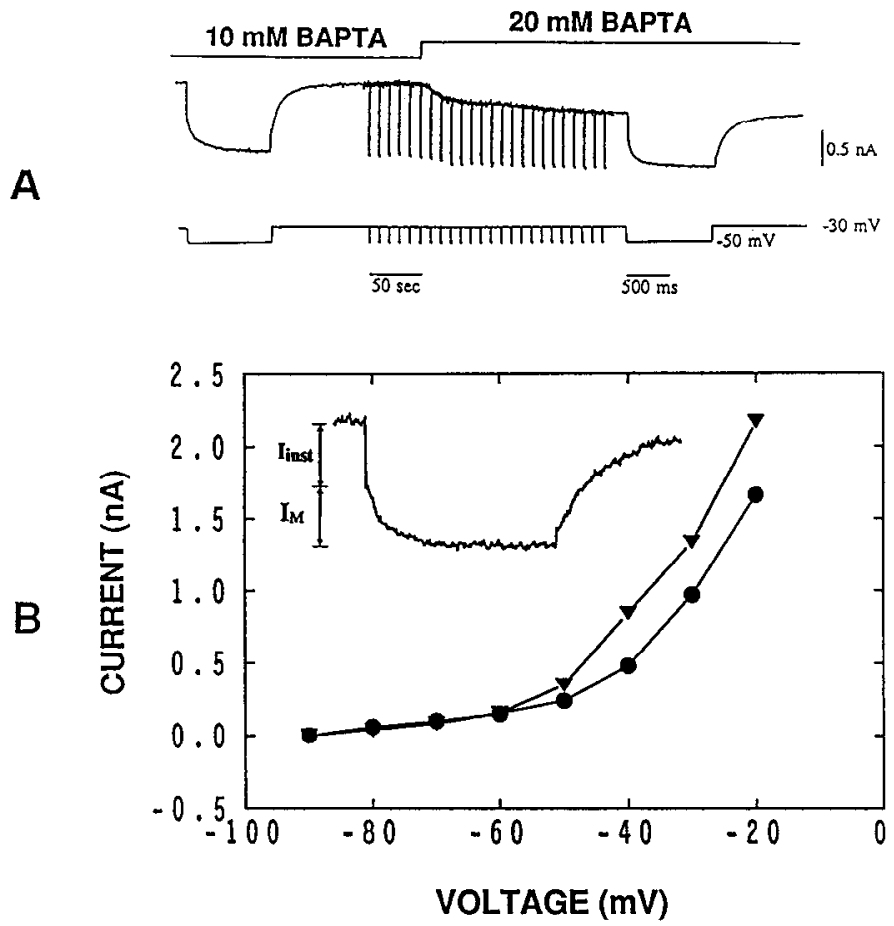

Figure 1. Effect of BAPTA on $I_{\mathrm{M}}$. A, Continuous recording in $10 \mathrm{~mm}$ and $20 \mathrm{~mm}$ BAPTA. The $\left[\mathrm{Ca}^{2+}\right]_{i}$ concentration was kept constant at $120 \mathrm{nM}$ throughout the experiment by adjusting the total added $\mathrm{Ca}^{2+}$; intracellular perfusion with $20 \mathrm{~mm}$ BAPTA decreased the current by about $20 \%$. B. The current-voltage $(I-V)$ relationships in $10 \mathrm{~mm}(\boldsymbol{\nabla})$ and $20 \mathrm{~mm}(0)$ BAPTA; the inset shows a representative trace. The instantaneous shift is part "leak" current and part M current and is referred to here as $I_{\text {inst }}$ (instantaneous). The amplitude of the current relaxation upon hyperpolarization provides a measure of the deactivation of $I_{\mathrm{M}}$ (Brown and Adams, 1980). In order to maximize control of free calcium, BAPTA is present at a concentration of $20 \mathrm{~mm}$ throughout this report, unless stated otherwise.

possible $(2-3 \mathrm{~mm})$ so that the distal end of the internal tube could be placed close $(\sim 500 \mu \mathrm{m})$ to the electrode tip to facilitate diffusion and dialysis. The other end of the internal tube led into the perfusion solution in a separate reservoir through a sealed outlet. Perfusion was initiated when negative pressure (4-5 psi) was applied to the inside of the electrode through a second sealed outlet. The flow could rapidly $(\sim 1 \mathrm{sec})$ change the solution in the distal part of the electrode. The perfusion usually was carried on for $3 \mathrm{~min}$, during which time about $0.5 \mathrm{ml}$ of solution flowed through. The internal perfusion flow was then shut off. The procedure could be repeated in the same cell several times using different internal solutions without detectable deterioration of the cell. Because dialysis of the cell can be affected by clogging of the electrode tip after seal formation, the input resistance of the cell was routinely checked during the experiment. Data were used only from cells where the input resistance was not significantly increased.

When $\left[\mathrm{Ca}^{2+}\right]_{i}$ was increased by adding $\mathrm{CaCl}_{2}$, a junction potential shift occurred. For example, a $+6 \mathrm{mV}$ junction potential was detected by raising free $\mathrm{Ca}^{2+}$ from zero to $120 \mathrm{nM}$. This junction potential was corrected by referring to the reversal potential or applying an equal opposite voltage by adjusting the input offset on the amplifier after intracellular perfusion. In later experiments calcium acetate was used instead of $\mathrm{CaCl}_{2}$ and no obvious shift of junction potential was detected.

Measurement of $M$ current. Most $\mathrm{M}$ channels are closed at membrane potentials negative to $-60 \mathrm{mV}$ (Brown and Adams, 1980). When the membrane potential is clamped at $-30 \mathrm{mV}$, a substantial fraction of the available $M$ channels are open (Brown and Adams, 1980; Adams et al., 1982a). A hyperpolarizing voltage step, which closes $M$ channels, results in an instantaneous ohmic current jump ( $I_{\text {Instantaneous }}$ ) followed by a slow $M$ channel closing relaxation. When the membrane potential is commanded back to $-30 \mathrm{mV} 1 \mathrm{sec}$ later, a relaxation associated with $\mathrm{M}$ channel reopening is seen (see inset, Fig. $1 B$ ). We generally measured the size of $I_{\mathrm{M}}$ as the closing relaxation induced by a $20 \mathrm{mV}$ hyperpolarizing step (from -30 to $-50 \mathrm{mV}$ ). The steady-state current $I_{\mathrm{ss}}\left(I_{\mathrm{M}}+\right.$ $I_{\text {Instantaneous }}$ ) upon the step was measured for constructing $I-V$ curves. The use of closing relaxations, rather than opening relaxations, minimized contamination of the measured $I_{\mathrm{M}}$ by other $\mathrm{K}^{+}$currents.

Inhibitory effect of BAPTA on $\mathrm{I}_{M}$. BAPTA is a useful $\mathrm{Ca}^{2+}$ buffer because of its high selectivity for $\mathrm{Ca}^{2+}$ over $\mathrm{Mg}^{2+}$. BAPTA is also much less affected by $\mathrm{pH}$ than is EGTA and can bind and release $\mathrm{Ca}^{2+}$ more quickly than EGTA (Tsien, 1980). Most experiments used BAPTA to control intracellular $\mathrm{Ca}^{2+}$. While BAPTA may exert direct actions on $\mathrm{Ca}^{2+}$ channels in rat sympathetic neurons (Beech et al., 1991), there is as yet no evidence that BAPTA directly binds to $\mathrm{K}^{+}$channels or inhibits $\mathrm{K}^{+}$currents. However, because a high concentration of BAPTA (20 mM) was used to clamp free calcium levels, the effects of BAPTA on $I_{\mathrm{M}}$ were evaluated by intracellular perfusion.

Experiments were initiated with an internal solution containing 120 nM free $\mathrm{Ca}^{2+}$ and $10 \mathrm{mM} \mathrm{BAPTA} ; I_{\mathrm{M}}$ was $640 \pm 20 \mathrm{pA}(n=4)$. The concentration of BAPTA was then raised to $20 \mathrm{~mm}$ by intracellular perfusion, while free calcium was kept constant by a compensatory increase in total calcium. The higher concentration of BAPTA appeared to reduce current relaxations and steady-state current $\left(I_{\mathrm{ss}}+I_{\mathrm{rs}}\right.$

Fig. $1 A, B)$. $I-V$ curves showed, however, that only the portion of outward rectification at potentials positive to $-60 \mathrm{mV}$ was reduced (Fig. $1 B)$. This outward current is generated by the progressive opening of $M$ channels over this voltage range (Adams et al., 1982a). In $20 \mathrm{~mm}$ BAPTA, $I_{\mathrm{M}}$ was reduced to $405 \pm 78 \mathrm{pA}$, that is, $64 \%$ of the $I_{\mathrm{M}}$ in 10 mM BAPTA $(p<0.05, n=4)$. This effect was reversed by perfusing back to the lower BAPTA solution. Another set of experiments was done in the reverse order, beginning with $20 \mathrm{~mm}$ BAPTA and then reducing BAPTA to $10 \mathrm{~mm}$. $I_{\mathrm{M}}$ was $495 \pm 120 \mathrm{pA}$ in $20 \mathrm{~mm}$ BAPTA and increased to $694 \pm 110 \mathrm{pA}$ in $10 \mathrm{~mm}$ BAPTA $(p<0.05, n=3)$. These observations suggest that BAPTA selectively inhibits $I_{\mathrm{M}}$.

While free calcium was held constant in these experiments, the increase in BAPTA from 10 to $20 \mathrm{~mm}$ did produce other changes, according to the ASYST program: free magnesium decreased from $252 \mu \mathrm{M}$ to $222 \mu \mathrm{M}$, while free ATP increased from $337 \mu \mathrm{M}$ to $371 \mu \mathrm{M}$. These changes are small relative to the twofold increase in BAPTA, making it likely that BAPTA contributes the most to the alteration in $I_{\mathrm{M}}$. Use of Harrison and Bers' $K_{D}$ for BAPTA does not affect the outcome of this experiment. Free calcium would be $160 \mathrm{~nm}$ at both levels of BAPTA tested and similar changes in free ATP and magnesium would result. Unless otherwise specified, the BAPTA concentration used throughout this article was $20 \mathrm{~mm}$. The $I_{\mathrm{M}}$ values obtained would therefore be somewhat lower than $I_{\mathrm{M}}$ values obtained in the absence of BAPTA.

Imaging with fluo-3. Changes in $\left[\mathrm{Ca}^{2+}\right]_{i}$ were visualized using the fluorescent indicator fluo-3 (Molecular Probes). Fluo-3 was the indicator of choice because of its compatibility with BAPTA. The more commonly used ratiometric indicators, fura- 2 and indo-1, function at UV wavelengths. This limits their usefulness when using BAPTA, which is also sensitive to UV light. While EGTA could be used with the ratiometric indicators, binding of calcium to EGTA releases protons and would be disruptive in the types of experiments performed here. The magnitude of fluo-3's responsiveness has been determined in cultured sympathetic neurons using intracellular perfusion (O'Malley et al., 1993), and therefore the magnitude of the calcium changes can be estimated using this indicator.

The patch-clamp electrode solution was as described above and additionally contained $100 \mu \mathrm{M}$ fluo-3 (pentapotassium salt). The cells were imaged using a Bio-Rad MRC 600 laser-scanning confocal imaging system using $488 \mathrm{~nm}$ excitation light and a Zeiss IM35 inverted microscope with a $50 \times, 1.0 \mathrm{NA}$ water-immersion objective (Leitz). For imaging experiments, the sympathetic ganglion cells were plated on a glass coverslip that was glued to a small Petri dish. A drop of water is placed on the microscope objective, which is then raised until the drop contacts the bottom of the coverslip. The objective is raised further until the cell comes into focus. The argon laserbeam was attenuated with a $2.0 \log$ neutral density filter and the aperture was set approximately one-third open. The specimens were slow scanned using Kalman averaging of five successive scans. Images were routinely taken at 2 or 3 min intervals. $\mathrm{Mn}^{2+}$ was omitted from the extracellular Ringer and replaced with $\mathrm{Mg}^{2+}$ to prevent quenching of the fluo-3 fluorescence (Kao et al., 1989).

Chemicals. BAPTA was purchased from Sigma or Biochemical (BDH Chemicals Ltd., Poole, England). FGTA, TFA, and $d$-tubocurarine (dTC) were from Sigma. Muscarine chloride was from Sigma or RBI (Research Biochemicals Incorporated, Natick, MA). IP ${ }_{3}$ was from RBI. 


\section{Results}

\section{Manipulation of free calcium by intracellular perfusion}

As a first check in verifying the efficacy of the intracellular perfusion technique, cells were perfused with different concentrations of $\mathrm{Na}^{+}$while measuring $\mathrm{Na}^{+}$current $\left(I_{\mathrm{Na}}\right.$; Joncs, 1987). Raising intracellular $\mathrm{Na}^{+}$from 8 to $115 \mathrm{~mm}$, by perfusing the patch pipette with high $\mathrm{Na}^{+}$solution, reversed the original inward $I_{\mathrm{Na}}$ to an outward current, consistent with the change in the $\mathrm{Na}^{+}$equilibrium potential. The change was essentially completed in $5.0 \pm 0.1 \mathrm{~min}(n=36)$. The alteration in $\mathrm{Na}^{+}$current was reversed by switching the internal perfusate back to the low $\mathrm{Na}^{+}$solution (see also Lopez, 1992).

While sodium appears to be well controlled by this technique, manipulation of intracellular calcium is potentially more problematic because of intracellular calcium binding sites, buffers, and storage organelles and because of calcium extrusion mechanisms such as the $\mathrm{Na}^{+} / \mathrm{Ca}^{2+}$ exchanger and the $\mathrm{Ca}^{2+}$ ATPase. To verify further the efficacy of intracellular perfusion, a laserscanning confocal fluorescence imaging system was used to visualize changes in intracellular $\mathrm{Ca}^{2+}$ during perfusion with different levels of free calcium. Patch-clamp recordings were made using electrodes filled with $100 \mu \mathrm{M}$ fluo-3, $20 \mathrm{~mm}$ BAPTA, and no added $\mathrm{Ca}^{2+}$. Because of the complexity of combining intracellular perfusion with laser-scanning microscopy, it was necessary to use slightly higher resistance electrodes (3-4 M 2 ) for these particular experiments.

During whole-cell recording, fluo-3 and BAPTA gradually diffused into the cell, as evidenced by a gradual fluorescence increase (Fig. $2 A$ ). The $\left[\mathrm{Ca}^{2+}\right]_{i}$ is expected to be in the very low nanomolar range due to the high concentration of BAPTA. After the image intensity approached a plateau, internal perfusion was initiated with a solution that contained $120 \mathrm{nM}$ free $\mathrm{Ca}^{2+}$, but was otherwise identical to the zero calcium solution (Fig. $2 A$, row II). As the perfusion proceeded, the cellular fluorescence became progressively brighter, approaching a plateau in about $12 \mathrm{~min}$ (the range was $5-15 \mathrm{~min}$ in 15 cells). Although the nucleus is brighter than the cytosol, due to a greater content of fluo-3 (O'Malley et al., 1993), the relative fluorescence increase was similar in the nucleus and cytoplasm. When the cell was subsequently perfused with a zero $\mathrm{Ca}^{2+}$ solution to reduce $\left[\mathrm{Ca}^{2+}\right]_{i}$ (row III), the cellular fluorescence decreased back toward the level initially present in zero calcium solution, showing that the change in intracellular calcium was reversible (Fig. $2 A$ ).

\section{Relationship between free calcium and $\mathrm{I}_{M}$}

The effect of $\mathrm{Ca}^{2+}$ on $I_{\mathrm{M}}$ was tested by perfusing the pipette with solutions containing different concentrations of free calcium. Most experiments were started in a nominally $\mathrm{Ca}^{2+}$-free environment, that is, with no $\mathrm{Ca}^{2+}$ added to either the inside or outside of the cells and with calcium chelator present on both sides (see Materials and Methods). In this condition (referred to as zero $\mathrm{Ca}^{2+}$; applies to the above imaging experiments as well), we consistently observed smaller $I_{\mathrm{M}}$ than in normal $\mathrm{Ca}^{2+}$, even immediately after breaking through the patch membrane. There were usually some slight increases or decreases of the current during the first few minutes. Experimental data were collected after 5-10 min, when the size of the current stabilized. $I_{\mathrm{M}}$ in $0 \mathrm{nM} \mathrm{Ca}^{2+}$ was $166 \pm 10 \mathrm{pA}(n=82)$. Upon raising $\left[\mathrm{Ca}^{2+}\right]_{i}, I_{\mathrm{M}}$ gradually increased. In some cells, $I_{\mathrm{M}}$ was monitored simultaneously with $\mathrm{Ca}^{2+}$ imaging (Fig. $2 A-C$ ) to visualize the relation between $\left[\mathrm{Ca}^{2+}\right]_{i}$ and $I_{\mathrm{M}}$. As shown in Figure $2 C$, the current was enhanced in parallel with the increase of fluorescence intensity as $\left[\mathrm{Ca}^{2+}\right]_{i}$ increased. Both fluorescence and current declined when the cell was again perfused with zero $\left[\mathrm{Ca}^{2+}\right]_{i}$. The parallel changes in image intensity and $I_{\mathrm{M}}$ demonstrates a correlation between $\left[\mathrm{Ca}^{2+}\right]_{i}$ and $I_{\mathrm{M}}$.

Once the enhanced $I_{\mathrm{M}}$ reached its peak, it remained at that level for as long as the recording lasted (10-30 min) (Fig. 3A). Low-resistance electrodes (1-2 M $)$ ) were used in the nonimaging experiments throughout this study; note that the time course by which changes in calcium modulated $M$ current (Fig. 3A) was similar to the time course of changes in sodium current described above and elsewhere (Lopez, 1992). The $I-V$ curves in Figure $3 B$ show that the outwardly rectifying $M$ current was selectively enhanced by increasing free calcium from $0 \mathrm{nM}$ to $120 \mathrm{nM} \mathrm{Ca}^{2+}$ via intracellular perfusion. The outward rectification moved to a lower level after returning to zero $\mathrm{Ca}^{2+}$, showing that the enhancement of $I_{\mathrm{M}}$ by $\mathrm{Ca}^{2+}$ was reversible. Changes of $I_{\mathrm{M}}$ could be reproduced in a single cell by successive internal perfusions; most of the data points, however, reflect experiments where calcium was raised, by a single perfusion change, from $0 \mathrm{nM}$ to one of the higher values illustrated. The reversal potential (about $-85 \mathrm{mV}$ ) remained the same after changing $\mathrm{Ca}^{2+}$. In order to rule out artifactual influences of the perfusion procedure on $I_{\mathrm{M}}$, some cells were perfused with the same internal perfusate, that is, from $0 \mathrm{nM} \mathrm{Ca}^{2+}$ to $0 \mathrm{nM} \mathrm{Ca}^{2+}$ or from $120 \cdot \mathrm{nM} \mathrm{Ca}{ }^{2+}$ to $120 \mathrm{nM} \mathrm{Ca}^{2+}$; no obvious alterations of $I_{\mathrm{M}}$ occurred.

The dose-response curve in Figure $3 C$ illustrates that the most substantial changes in $I_{M}$ occurred between 0 and $60 \mathrm{nM} \mathrm{Ca}^{2+}$. Increasing calcium from $0 \mathrm{nM}$ to $60 \mathrm{nM}$ enhanced $I_{\mathrm{M}}$ by about twofold (ratio of post- to preperfusion, $2.08 \pm 0.25 ; n=12 ; p$ $<0.05$ ). Calcium levels higher than $60 \mathrm{nM}$, reached either by starting from $0 \mathrm{nM} \mathrm{Ca}^{2+}$ or by successive perfusions in a single cell, produced only limited further increases of $I_{\mathrm{M}}$ (Fig. 3C). For example, in cells initially recorded at $120 \mathrm{nM} \mathrm{Ca}^{2+}, I_{\mathrm{M}}$ was 351 $\pm 61 \mathrm{pA}$. $\left[\mathrm{Ca}^{2+}\right]_{i}$ was then increased to $240 \mathrm{nM}$ (a "net" 120 nM increase in free $\left.\mathrm{Ca}^{2+}\right) . I_{\mathrm{M}}$ recorded after the perfusion was $374 \pm 79 \mathrm{pA}(n=3)$, a ratio of 1.06 relative to the $I_{\mathrm{M}}$ before the perfusion. Raising $\mathrm{Ca}^{2+}$ beyond $400 \mathrm{nM}$ tended to reduce $I_{\mathrm{M}}$ as compared to 60 or $240 \mathrm{nM} \mathrm{Ca}^{2+}$. The amplitude of $I_{\mathrm{M}}$ was $278 \pm 58 \mathrm{pA}(n=8)$ when $\mathrm{Ca}^{2+}$ was raised to $450 \mathrm{nM}$, although this value was still larger than when the current was measured at zero $\mathrm{Ca}^{2+}$ (Fig. 3C).

Since some authors suggested that a $\mathrm{Ca}^{2+}$ binding site on the outside of the membrane might modulate the opening of $\mathbf{M}$ channels (Tokimasa and Akasu, 1990a), we also examined whether changing extracellular calcium levels would modulate $I_{\mathrm{M}}$. The experiments were started in the $\mathrm{Ca}^{2+}$-free environment described above. $I_{\mathrm{M}}$ was $184 \pm 83 \mathrm{pA}(n=14)$. The extracellular $\mathrm{Ca}^{2+}$-free Ringer was then switched to a Ringer containing 2 $\mathrm{mM} \mathrm{CaCl}_{2}$ (in place of $2 \mathrm{mM} \mathrm{MnCl}$ ), and $I_{\mathrm{M}}$ increased to 203 $\pm 111 \mathrm{pA}$. This change was insignificant at a $10 \%$ level $(1.11$ $\pm 0.47, n=14 ; p>0.05$ ). Calcium imaging studies showed only minuscule changes in cellular fluorescence when switching between these Ringer solutions.

In $\mathrm{Ca}^{2+}$-free solution, there will be more free BAPTA available than in the $120 \mathrm{nM} \mathrm{Ca}^{2+}$ solution, since total BAPTA is held constant at $20 \mathrm{~mm}$. Because BAPTA had an inhibitory effect on $I_{\mathrm{M}}$, it was possible that the enhancement of $I_{\mathrm{M}}$ in 120 nM free calcium resulted from the lowering of free BAPTA (a greater proportion of the BAPTA now being complexed with calcium). To explore this possibility, the free BAPTA was main- 
A

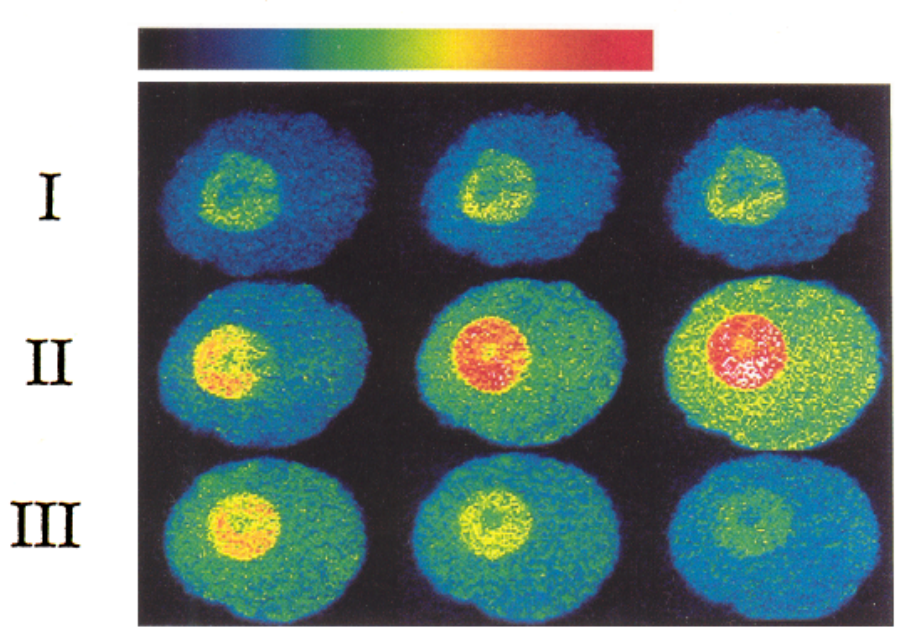

B
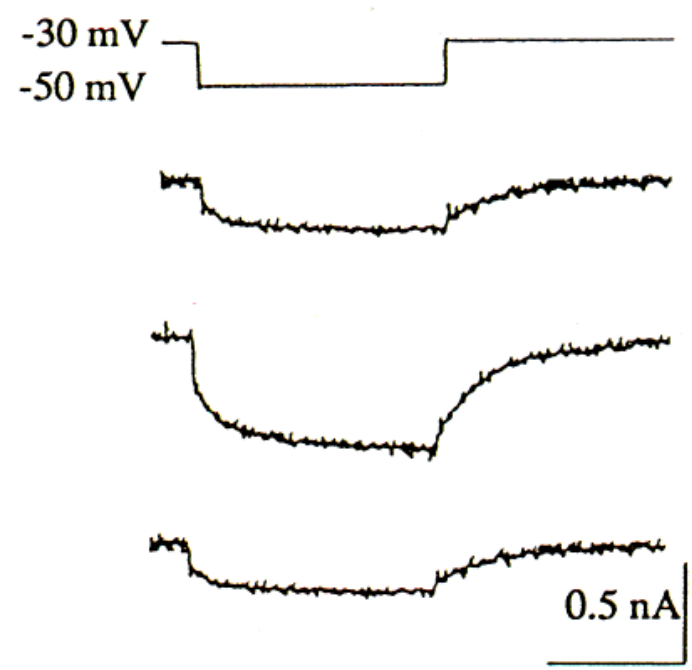

$500 \mathrm{~ms}$

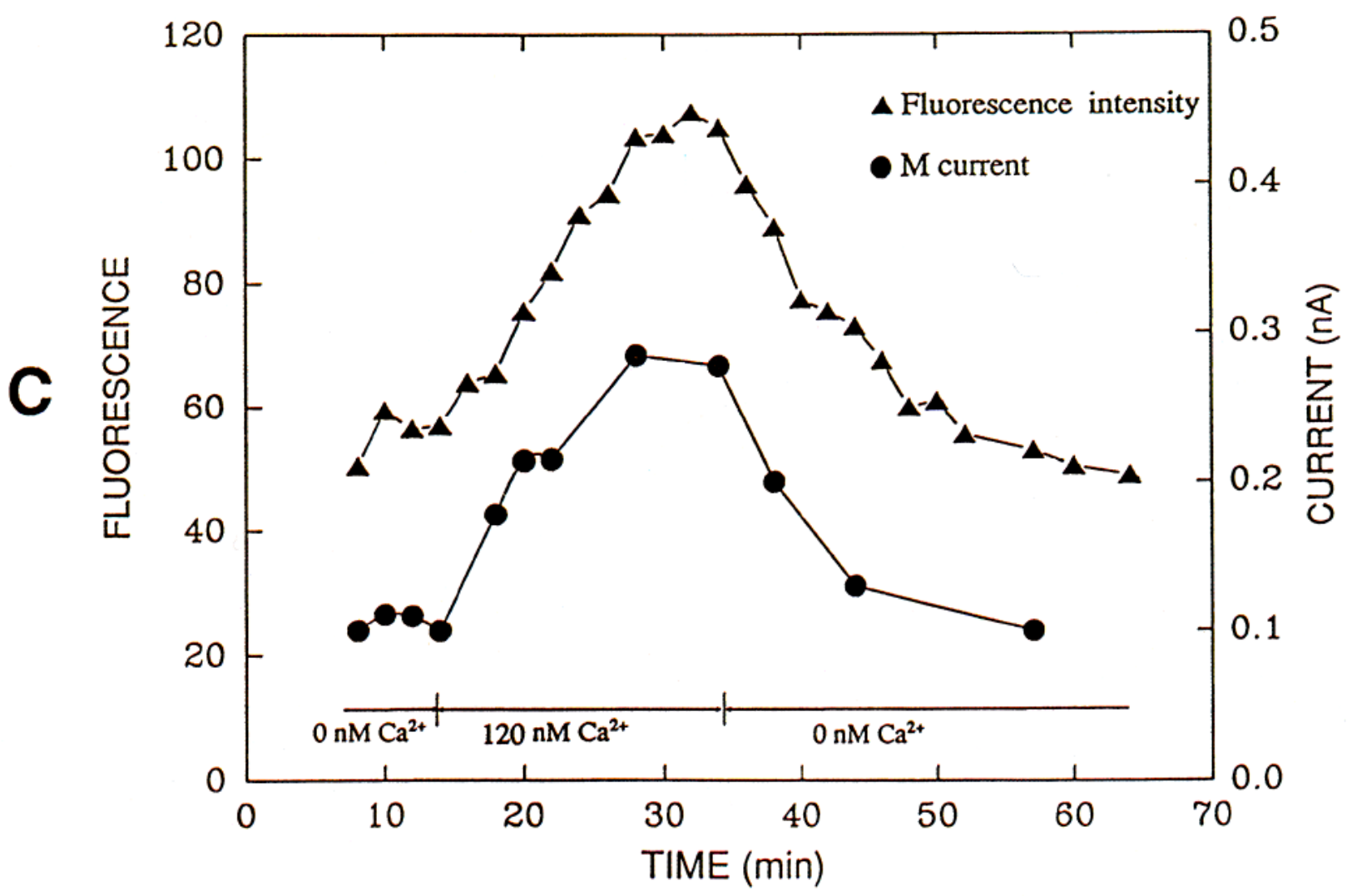

Figure 2. Manipulation of free calcium by intracellular perfusion. Fluo-3 (100 $\mu \mathrm{M})$ and BAPTA (20 mM) were included in all internal solutions. Images were acquired via confocal laser-scanning microscopy (Bio-Rad MRC 600). Whole-cell currents were simultaneously recorded in the same neurons. $A$, Images were acquired at about $3 \mathrm{~min}$ intervals; representative images acquired during cell filling and successive perfusions are shown. $B$. The current traces correspond to the last image in each of the three rows of $A: I$, fluo- 3 and BAPTA were loaded into the cell with zero Ca ${ }^{2+}$; $I I$, during perfusion with $120 \mathrm{nM} \mathrm{Ca}^{2+} ; I I I$, the cell was perfused back to zero $\mathrm{Ca}^{2+} . C$, Parallel changes in fluorescence intensity (arbitrary units) or free calcium and $I_{\mathrm{M}}$ occur during the successive intracellular perfusions. Fluorescence intensity was taken as the average of the measurements from the cytosol and the nucleus. For imaging experiments, electrodes of higher resistance were used ( $3-4 \mathrm{M} \Omega ; 3 \mathrm{M} \Omega$ in this instance). Thus, the time course of reaching a plateau, for example, about $12 \mathrm{~min}$ in row II, is longer than in the nonimaging experiments in this report, where lower resistance electrodes were used. 

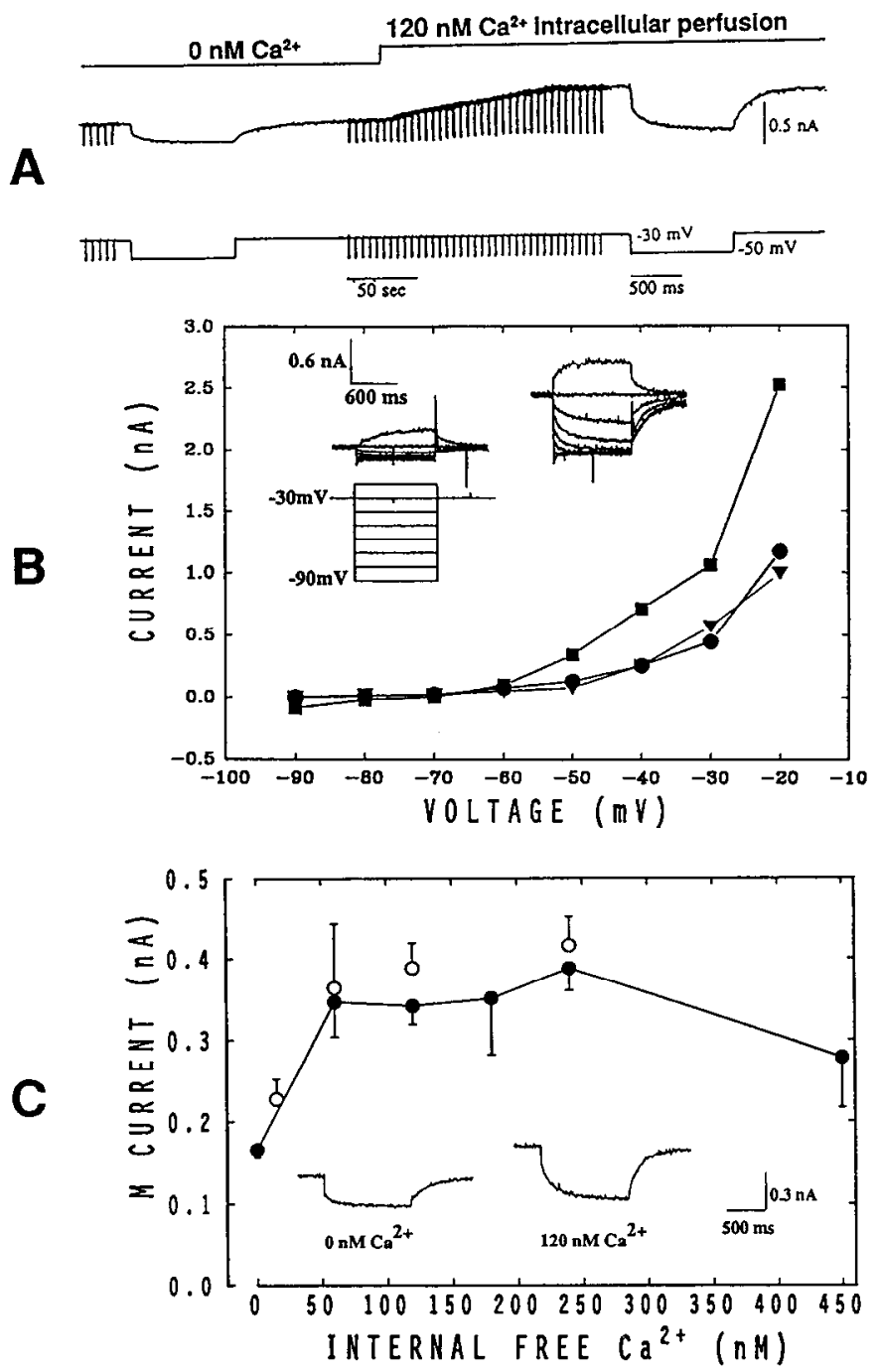

Figure 3. Effect of free calcium on $I_{\mathrm{M}} . A$, Continuous recording in 0 $\mathrm{nM}$ and $120 \mathrm{nM} \mathrm{Ca}^{2+} . B, I-V$ relationships before $(\bullet)$ and during $(\square)$ perfusion with $120 \mathrm{nM} \mathrm{Ca}^{2+}$, followed by perfusion back to $0 \mathrm{nM} \mathrm{Ca}^{2+}$ ( $\nabla)$. The inset shows the superimposed current traces before (left) and during (right) the $120 \mathrm{nM} \mathrm{Ca}^{2+}$ perfusion. $C$, Dose-response curve obtained from perfused $(\Theta)$ and nonperfused $(O)$ cells. Data for the perfused cells were principally acquired in experiments where calcium was raised from $0 \mathrm{~nm}$ to one of the higher levels of calcium shown. The two representative examples of $M$ current shown were obtained in 0 nM and $120 \mathrm{nM} \mathrm{Ca}^{2+}$. $V_{\text {hold }},-30 \mathrm{mV} ; V_{\text {step, }},-20 \mathrm{mV}$ for $1 \mathrm{sec}$.

tained constant while $\mathrm{Ca}^{2+}$ was varied. For the $\mathrm{Ca}^{2+}$-free solution, $11.4 \mathrm{~mm}$ total BAPTA was used, while $20 \mathrm{~mm}$ BAPTA was used in the $120 \mathrm{nM} \mathrm{Ca}^{2+}$ solution. The amount of free BAPTA was calculated to be the same in both solutions. Under these conditions, $I_{\mathrm{M}}$ was $382 \pm 71 \mathrm{pA}$ in $0 \mathrm{Ca}^{2+}$ and augmented to $825 \pm 96 \mathrm{pA}(n=3)$ after $120 \mathrm{nM} \mathrm{Ca}^{2+}$ perfusion. Thus, $I_{\mathrm{M}}$ was again about doubled in $120 \mathrm{nM} \mathrm{Ca}^{2+}$ (2.16-fold increase), while free BAPTA was held constant, eliminating changes in free BAPTA as a cause of the augmentation of $I_{\mathrm{M}}$.

An alternative $\mathrm{Ca}^{2+}$ chelator EGTA (20 mM) was substituted for BAPTA in some experiments. $I_{\mathrm{M}}$ was $83 \pm 70 \mathrm{pA}$ at $0 \mathrm{nM}$ $\mathrm{Ca}^{2+}$ and rose to $275 \pm 34 \mathrm{pA}(n=14)$ after $80 \mathrm{nM} \mathrm{Ca}^{2+}$ perfusion, a 3.3-fold increase. This further indicates that alterations of $I_{\mathrm{M}}$ after raising $\left[\mathrm{Ca}^{2+}\right]_{i}$ are not due to direct effects of BAPTA.

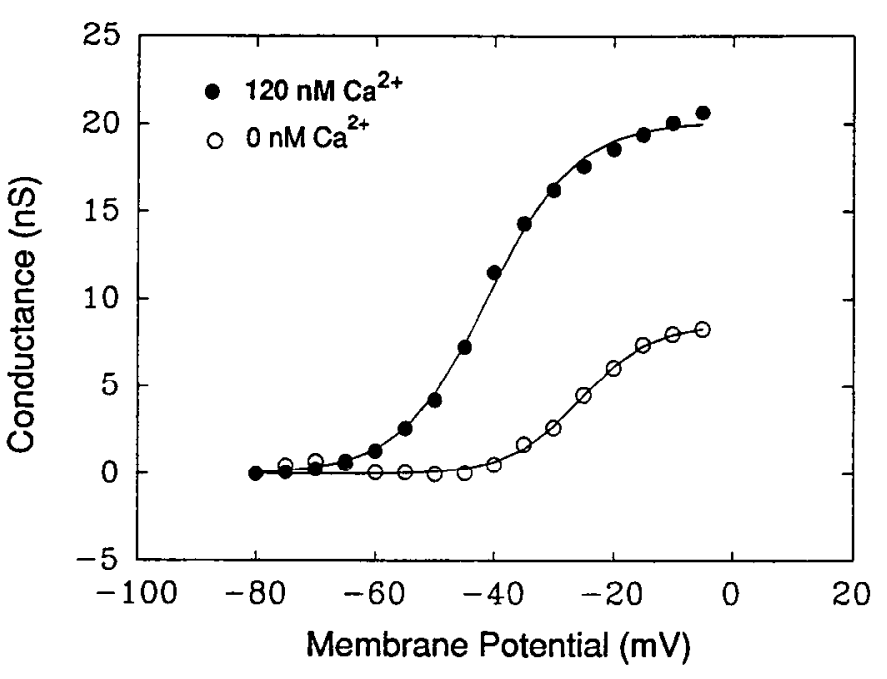

Figure 4. Calcium affects the activation of $I_{\mathrm{M}}$. Activation curves were obtained before $(O)$ and after $(0)$ raising $\left[\mathrm{Ca}^{2+}\right]_{i}$ from $0 \mathrm{nM}$ to $120 \mathrm{nM}$. The curves were fitted by the Boltzmann equation $G=G_{\max }\{[1+$ $\left.\exp \left(\left(V_{\text {half }}-V\right) / A\right)\right]^{-1}$ \{, where $V$ is membrane potential; $V_{\text {half }}$ the potential for half activation; and $A$, the slope factor (Adams et al., 1982a). The channels were mostly closed at voltages negative to $-60 \mathrm{mV}$. Raising $\left[\mathrm{Ca}^{2+}\right]_{i}$ enhanced the conductance and shifted its voltage sensitivity. The experiment was done with $5 \mathrm{mM}$ TEA, $1 \mathrm{~mm}$ 4-aminopyridine, 1 mM cesium, $3 \mu \mathrm{M}$ TTX in the external Ringer. Cesium was used to block the slow sodium-potassium inward $\mathrm{H}$ current (Tokimasa and Akasu, 1990b), which may be activated by the hyperpolarization jumps used to close the M channels.

\section{Electrophysiological controls}

Switching between internal solutions can create liquid junction potentials that could change the true size of the holding potential and subsequently affect the size of voltage-dependent currents. Although the junction potential was carefully checked and corrected (see Materials and Methods), some nonperfusion experiments were carried out to avoid this possible artifact. Patchclamp electrodes were initially filled with solutions containing different concentrations of free $\mathrm{Ca}^{2+}$. The electrode "input" offset was compensated to zero at the beginning of each experiment and checked at the end. Thus, these nonperfusion experiments eliminated potential errors arising from the intracellular perfusion procedure, particularly any errors that might have resulted from the switching of solutions. $I_{\mathrm{M}}$ was measured in cells initially dialyzed with $0,15,60,120$, and $240 \mathrm{nM}$ free $\mathrm{Ca}^{2+}$ (open circles, Fig. $3 C$ ). The amplitude of $I_{\mathrm{M}}$ varied systematically at each $\mathrm{Ca}^{2+}$ concentration. $I_{\mathrm{M}}$ values obtained from perfusion and nonperfusion experiments coincided quite well. $I_{\mathrm{M}}$ at $60 \mathrm{nM}$ or higher $\mathrm{Ca}^{2+}$ was always more than two times larger than $I_{\mathrm{M}}$ at $0 \mathrm{nM} \mathrm{Ca}{ }^{2+}$.

In some experiments, the membrane potential was held at $-60 \mathrm{mV}$ during the $0-120 \mathrm{nM} \mathrm{Ca}^{2+}$ perfusion. After $5-10 \mathrm{~min}$ of perfusion with $120 \mathrm{nM}$ calcium, the holding potential was stepped to $-30 \mathrm{mV}$, and the size of $I_{\mathrm{M}}$ was immediately measured. The increase in $I_{\mathrm{M}}$ was found to be the same as in experiments where the cell was held at $-30 \mathrm{mV}$ during the switch. $I_{\mathrm{M}}$ increased 2.13-fold $(n=3)$ after the perfusion. This indicates that the enhancement of $I_{M}$ by calcium occurs independently of voltage; thus, the effects of calcium occurred regardless of whether the channels were mostly open $(-30 \mathrm{mV})$ or largely closed $(-60 \mathrm{mV})$.

Intracellular perfusion with raised $\mathrm{Ca}^{2+}$ also enhanced mem- 

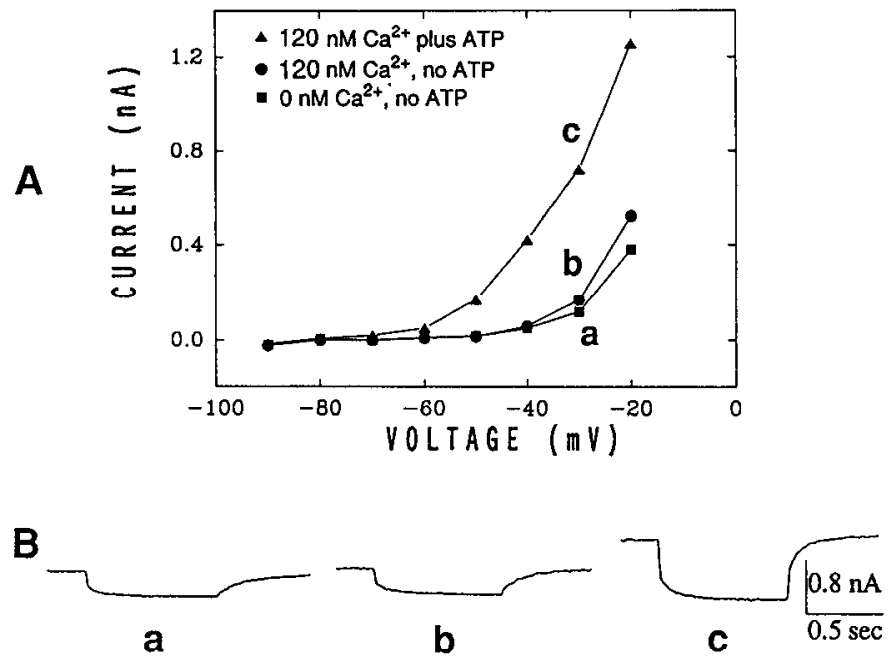

Figure 5. ATP is required for the calcium-dependent enhancement of $I_{\mathrm{M}} . A$, The $I-V$ relationship of voltage and $\mathrm{M}$ current; $\square$, the basal $\mathrm{M}$ current in a Ca ${ }^{2+}$-free environment. Perfusion with $120 \mathrm{nM} \mathrm{Ca}^{2+}$ without ATP (O) failed to increase the current significantly. Addition of $1.5 \mathrm{~mm}$ ATP to the perfusion solution, in the continued presence of $120 \mathrm{nM}$ $\mathrm{Ca}^{2+}(\mathbf{A})$, considerably enhanced the current at voltages positive to -60 $\mathrm{mV} . B$, The three current traces correspond to the respective $I-V$ curves in $A$. $V_{\text {hold }},-30 \mathrm{mV} ; V_{\text {step }},-20 \mathrm{mV}$ for $1 \mathrm{sec}$.

brane conductance. The membrane chord conductance $\left(G_{\mathrm{CH}}\right)$ increased $7.93 \mathrm{nS}$ from $0 \mathrm{nM} \mathrm{Ca}^{2+}(11.83 \pm 1.48 \mathrm{nS})$ to $120 \mathrm{nM}$ $\mathrm{Ca}^{2+}\left[19.76 \pm 1.87 \mathrm{nS} ; n=23, p<0.05 ; G_{\mathrm{CH}}=I_{\text {instantaneous }}(V) /\right.$ $\left.\left(V-V_{H}\right), V=-50 \mathrm{mV}, V_{H}=-30 \mathrm{mV}\right]$. Figure 4 shows the activation curves of $I_{\mathrm{M}}$ before and after $120 \mathrm{nM} \mathrm{Ca}^{2+}$ perfusion. At $0 \mathrm{nM} \mathrm{Ca}^{2+}, \mathrm{M}$ channels were mostly closed at potentials negative to $-50 \mathrm{mV}$. The maximum conductance $\left(G_{\max }\right)$ was $8.5 \mathrm{nS}$ with a half-activation potential $\left(V_{\text {half }}\right)$ of $-26 \mathrm{mV}$. Raising $\mathrm{Ca}^{2+}$ shifted the curve upward, increasing $G_{\max }$ to $20.1 \mathrm{nS}$. In addition, the voltage dependence of $\mathrm{M}$ channels moved toward more negative potentials. $V_{\text {half }}$ became $-41 \mathrm{mV}$ in this instance (Fig. 4). The average shift of $V_{\text {half }}$ was $-11 \pm 6 \mathrm{mV}$ in four analyzed cells.

ATP is required for maintaining $I_{\mathrm{M}}$ (Pfaffinger, 1988). We observed that when ATP was omitted from the electrode solution $I_{\mathrm{M}}$ gradually declined (the "rundown" of $I_{\mathrm{M}}$ ) even when normal $\mathrm{Ca}^{2+}$ was present. To test whether ATP was necessary for $I_{\mathrm{M}}$ enhancement, $\left[\mathrm{Ca}^{2+}\right]_{i}$ was raised without ATP in the internal solution. Intracellular perfusions were initiated to raise $\left[\mathrm{Ca}^{2+}\right]_{i}$, in the absence of exogenous ATP, about $5 \mathrm{~min}$ after establishing the whole-cell recording configuration. $I_{\mathrm{M}}$ did not increase when $\left[\mathrm{Ca}^{2+}\right]_{i}$ was raised to $120 \mathrm{nM}$ (ratio of $1.03 \pm$ $0.11 ; n=5)$. Figure 5 shows that raising $\left[\mathrm{Ca}^{2+}\right]_{i}$ to $120 \mathrm{nM}$, with no ATP in the perfusate, produced little effect on $I_{\mathrm{M}}$ or the $I-V$ relationship. Upon addition of $1.5 \mathrm{~mm} \mathrm{ATP} \mathrm{to} \mathrm{the} \mathrm{perfusate,}$ however, the outward rectification of the $I-V$ curve was enhanced, due to the progressive opening of $\mathrm{M}$ channels.

Bullfrog sympathetic ganglion cells exhibit several potassium currents in addition to $I_{\mathrm{M}}$, some of which are $\mathrm{Ca}^{2+}$ dependent ( $I_{\mathrm{C}}, I_{\mathrm{AHP}}$; Adams et al., 1982a; Pennefather et al., 1985). To confirm that the current enhanced by $\mathrm{Ca}^{2+}$ was indeed $I_{\mathrm{M}}$, the following experiments were conducted. First, the current was identified as a $\mathrm{K}^{+}$current by changing the external $\mathrm{K}^{+}$concentration. After raising $\left[\mathrm{Ca}^{2+}\right]_{i}$ from 0 to $120 \mathrm{nM}$, the current showed a reversal potential of $-90 \mathrm{mV}$ in normal Ringer (2.5 $\mathrm{mm} \mathrm{KCl}$ ). Upon increasing external potassium to $10 \mathrm{~mm}$, the

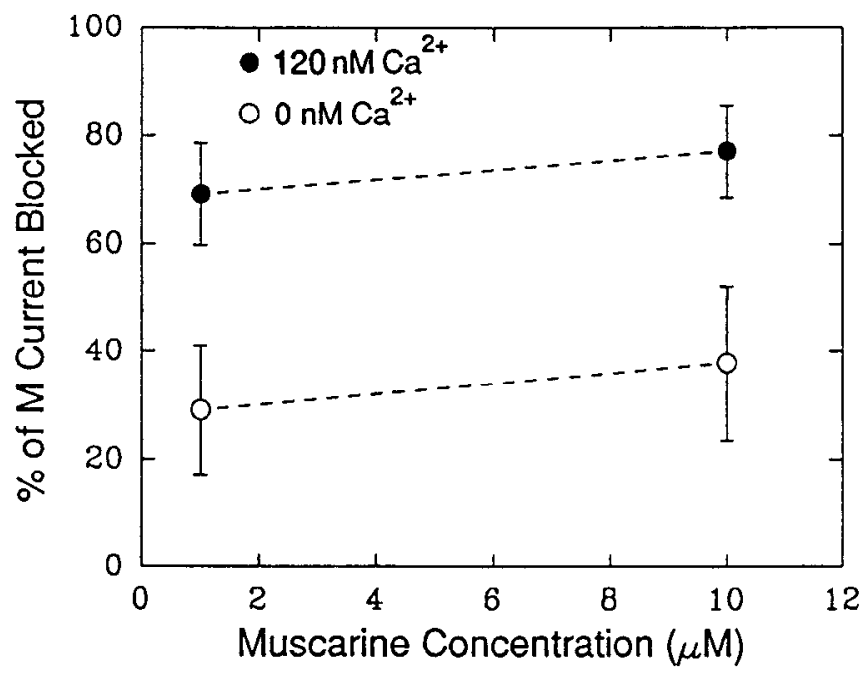

Figure 6. Muscarinic inhibition of $I_{\mathrm{M}}$ is affected by free calcium. Cells were divided into four groups; each group contained five cells $(n=5)$. Each point in the graph represents the data from one group. Muscarine ( 1 and $10 \mu \mathrm{M}$ ) was tested at $0 \mathrm{nM}(0)$ and $120 \mathrm{nM}(\bullet) \mathrm{Ca}^{2+}$, respectively. Both concentrations of muscarine produced larger reductions in current at $120 \mathrm{~nm}$ calcium then at $0 \mathrm{nM}$ calcium.

reversal potential shifted to about $-60 \mathrm{mV}$. Both reversal potentials were similar to the values predicted by the Nernst equation. This shows that the current increased by $\mathrm{Ca}^{2+}$ was principally carried by $\mathrm{K}^{+}$.

TEA ( $5 \mathrm{~mm}$ ) was applied in the bathing medium to block $I_{\mathrm{K}}$ and $I_{C}$ (Adams et al., 1982b), and $d$-tubocurarine (d-TC; 100 $\mu \mathrm{M}$ ) was used to block $I_{\mathrm{AHP}}$ (Pennefather et al., 1985; Goh and Pennefather, 1987). Neither of these agents prevented the increase in $\mathrm{K}^{+}$current normally produced by raising $\left[\mathrm{Ca}^{2+}\right]_{i}, I_{\mathrm{M}}$ was enhanced $2.54 \pm 0.21$-fold $(n=4)$ and $2.80 \pm 0.86$-fold $(n=3)$ in the presence of TEA and d-TC, respectively. To construct the activation curves (Fig. 4), the external Ringer contained TEA (5 mM), 4-aminopyridine (1 mM), cesium (1 $\mathrm{mm}$ ), and TTX $(3 \mu \mathrm{M})$. In the presence of this group of compounds, the $M$ conductance was still enhanced by raising $\left[\mathrm{Ca}^{2+}\right]_{i}$. These results rule out substantial contributions from other $\mathrm{K}^{+}$currents.

The $\mathrm{M}$ channel is tonically active at the holding potential of $-30 \mathrm{mV}$; hence, the standing outward holding current at -30 $\mathrm{mV}$ reflects the size of $I_{\mathrm{M}}$ (Bosma et al., 1990). It was thus expected that the holding current should be smaller in $0 \mathrm{Ca}^{2+}$ than in higher $\mathrm{Ca}^{2+}$. This prediction was confirmed. The holding current at $-30 \mathrm{mV}$ was $245 \pm 61 \mathrm{pA}(n=26)$ at $0 \mathrm{Ca}^{2+}$ and increased to $651 \pm 84 \mathrm{pA}$ after perfusion with $120 \mathrm{nM} \mathrm{Ca}^{2+}$. The holding current was increased 2.65 -fold by raising $\left[\mathrm{Ca}^{2+}\right]_{i}$ $(p<0.05)$, similar to the $I_{\mathrm{M}}$ increase measured from the closing relaxation (a ratio of 2.11 ).

\section{Muscarinic modulation of $\mathrm{I}_{M}$ : effects of calcium}

The effects of muscarine were measured at different levels of free calcium to examine the role of $\mathrm{Ca}^{2+}$ in $I_{\mathrm{M}}$ suppression and overrecovery. To avoid desensitization of muscarinic receptors, muscarine was usually applied only once to each cell, typically for about 20 or $30 \mathrm{sec}$, which allowed muscarine to attain its maximal effect. When two muscarine tests were conducted in a single cell, the cell was extensively washed by drug-free Ringer and there was at least $10 \mathrm{~min}$ between applications of muscarine. 
$120 \mathrm{nM} \mathrm{Ca}^{2+}$

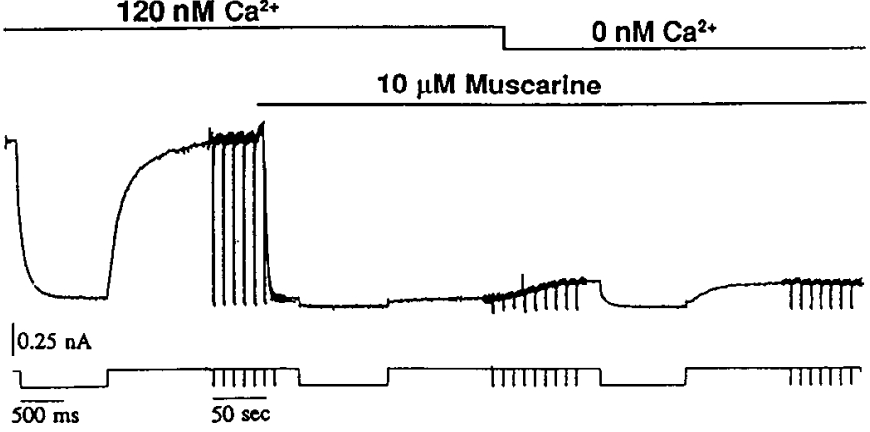

Figure 7. Calcium plays a role in sustained suppression of $I_{\mathrm{M}}$. A decrease in $\left[\mathrm{Ca}^{2+}\right]_{i}$ by intracellular perfusion resulted in a partial recovery of $I_{\mathrm{M}}$ that had been blocked by $10 \mu \mathrm{M}$ muscarine. The cell was first recorded at $120 \mathrm{nM} \mathrm{Ca}^{2+}$ and $I_{\mathrm{M}}$ was totally suppressed by muscarine. In the continued presence of $10 \mu \mathrm{M}$ muscarine in the bathing solution, a reduction in $\left[\mathrm{Ca}^{2+}\right]_{i}$ by intracellular perfusion of zero $\mathrm{Ca}^{2+}$ caused a substantial increase in $I_{\mathrm{M}}$.

At $0 \mathrm{nM} \mathrm{Ca}{ }^{2+}, 1 \mu \mathrm{M}$ muscarine produced about a 30\% (0.29 \pm $0.11, n=8)$ reduction of $I_{\mathrm{M}}$, while $70 \%(0.69 \pm 0.09, n=6)$ of $I_{\mathrm{M}}$ was blocked at $120 \mathrm{nM} \mathrm{Ca}^{2+}$ (Fig. 6). Increasing the concentration of muscarine to $10 \mu \mathrm{M}$ slightly increased inhibition of $I_{\mathrm{M}}$ at both levels of free calcium, but muscarine was still much more effective at $120 \mathrm{nM}$ calcium. At $0 \mathrm{nM} \mathrm{Ca}^{2+}, 40 \%$ of $I_{\mathrm{M}}$ was blocked $(0.38 \pm 0.14, n=4)$, while the blockage was about $80 \%$ $(0.77 \pm 0.08, n=4)$ at $120 \mathrm{~nm} \mathrm{Ca}^{2+}$ (Fig. 6). Similar results were obtained for $\mathrm{LHRH}$. At $0 \mathrm{nM} \mathrm{Ca}^{2+}, 1 \mu \mathrm{M}$ LHRH blocked $59 \pm 17 \%(n=4) I_{\mathrm{M}}$, while $85 \pm 6 \%(n=11)$ of the current was blocked at $120 \mathrm{~nm} \mathrm{Ca}^{2}$.

The following experiments were designed to test whether reducing $\left[\mathrm{Ca}^{2+}\right]_{i}$ during exposure to agonist could influence the suppression of $I_{\mathrm{M}}$. Starting with $120 \mathrm{nM}\left[\mathrm{Ca}^{2+}\right]_{i}, 10 \mu \mathrm{M}$ muscarine essentially eliminated $I_{\mathrm{M}}$. In the continued presence of muscarine, intracellular perfusion was started to reduce $\left[\mathrm{Ca}^{2+}\right]_{i}$. Earlier, it was shown that zero calcium effectively reduced $I_{\mathrm{M}}$. However, under this condition, the $0 \mathrm{nMCa}^{2+}$ perfusion resulted in a partial recovery of the current suppressed by muscarine ( $n$ $=3$; Fig. 7). This implies that a minimal amount of $\mathrm{Ca}^{2+}$ is required for the sustained suppression of $I_{\mathrm{M}}$ by muscarine. This is not an artifact of the perfusion procedure, since reducing calcium normally decreases $I_{\mathrm{M}}$ rather than increasing it. The lessening of the muscarinic suppression does not appear to be a result of receptor desensitization. In two control experiments, when muscarine $(10 \mu \mathrm{M})$ was maintained in the bathing medium for the same period of time (5-6 min) without changing $\left[\mathrm{Ca}^{2+}\right]_{i}$, $I_{\mathrm{M}}$ suppression was faithfully maintained. Also, the time course of the increase in $I_{\mathrm{M}}$ parallels the change in calcium level. A very different time course would be expected for desensitization of muscarinic receptors.

The level of free calcium also has dramatic effects on the overrecovery of $\mathrm{M}$ current that occurs after removal of muscarine (Fig. 8). With $120 \mathrm{~nm} \mathrm{Ca}^{2+}$ present, upon washout of 10 $\mu_{\mathrm{M}}$ muscarine, $I_{\mathrm{M}}$ transiently overrecovered by $50 \%(150 \pm 10 \%$ recovery; $n=9$ ), compared with its control level before muscarine. When muscarine was tested at $0 \mathrm{nM} \mathrm{Ca}^{2+}$, although the suppressed current eventually returned to its original size after removing muscarine there was little overrecovery. The recovery of $I_{\mathrm{M}}$ averaged $106 \pm 5 \%(n=19)$ of the control current recorded before muscarine. A similar effect was found with LHRH. At zero $\mathrm{Ca}^{2+}$, there was only a $113 \pm 11 \%(n=4)$ recovery, while
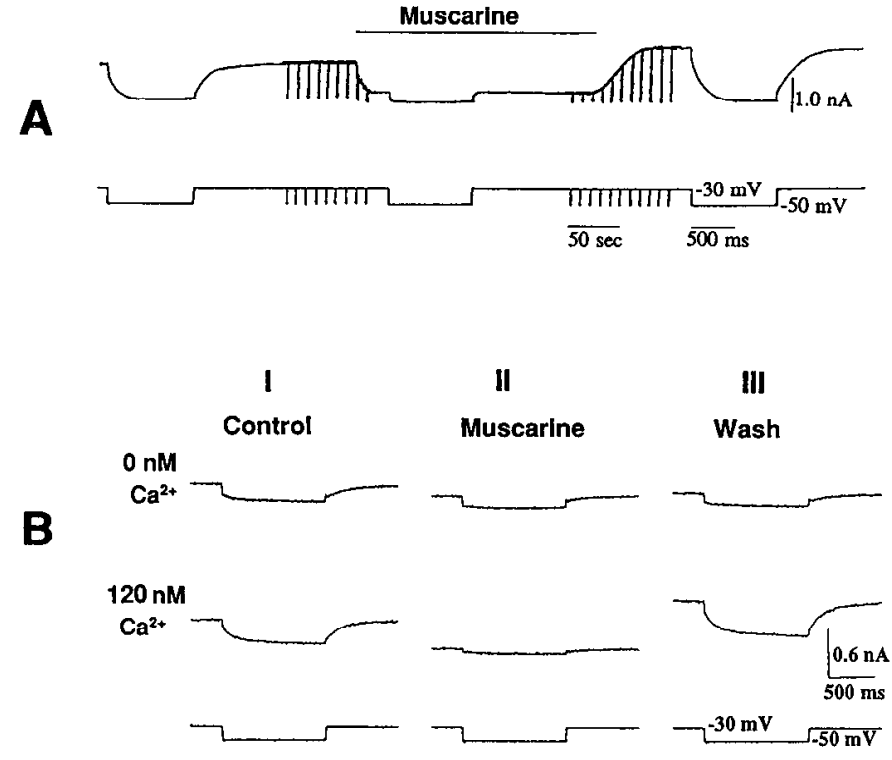

Figure 8. Effects of free calcium on overrecovery. $A$, Continuous recording in $120 \mathrm{nM}\left[\mathrm{Ca}^{2+}\right]_{i}$ shows that normal muscarinic suppression of $I_{\mathrm{M}}$ and overrecovery of $I_{\mathrm{M}}$ are observed in the presence of $20 \mathrm{mM}$ BAPTA. $I_{\mathrm{M}}$ was mostly blocked by $2 \mu \mathrm{M}$ muscarine and overrecovered upon washout of muscarine. $B$, The effects of muscarine $(10 \mu \mathrm{M})$ are shown in a representative cell recorded at $0 \mathrm{nM}$ and $120 \mathrm{nM}\left[\mathrm{Ca}^{2+}\right]_{i}$. The following recordings were made at each calcium level: $I$, control recording; $I I, 30 \mathrm{sec}$ after bath application of $10 \mu \mathrm{M}$ muscarine; and $I I I$, 1 min after washout of muscarine with drug-free Ringer. $I_{\mathrm{M}}$ was noticeably smaller in $0 \mathrm{Ca}^{2+}$, and inhibited less by muscarine ( $51 \%$ block) than it was in $120 \mathrm{nM} \mathrm{Ca}^{2+}(96 \%$ block $) . I_{\mathrm{M}}$ only partially recovered (75\% recovery) after $1 \mathrm{~min}$ of washout of muscarine at $0 \mathrm{~nm} \mathrm{Ca}^{21}$, while it overrecovered ( $150 \%$ recovery) following the same procedure at 120 $\mathrm{nM} \mathrm{Ca}{ }^{2+}$. Notice that the recovery of $I_{\mathrm{M}}$ after the second application of muscarine was greater than the first one; this was never observed when $\left[\mathrm{Ca}^{2+}\right]_{i}$ was kept constant. The presence of $20 \mathrm{~mm}$ BAPTA in these experiments should prevent the occurrence of calcium transients that would normally result from application of muscarine (Marrion et al., 1991; O’Malley et al., 1993).

an $88 \%$ "overshoot" of $I_{M}(188 \pm 25 \%$ recovery; $n=10)$ appeared in $120 \mathrm{nM} \mathrm{Ca}^{2+}$ after removal of $1 \mu \mathrm{M}$ LHRH.

Overrecovery normally diminishes following repeated application of agonists. Under consistent conditions, the second application of muscarine always produces less overrecovery than the previous one. Muscarine responses were examined in single cells before and after raising $\left[\mathrm{Ca}^{2+}\right]_{i}$. The initial $10 \mu \mathrm{M}$ muscarine applied at $0 \mathrm{nM} \mathrm{Ca}^{2+}$ was followed by a $110 \pm 5 \%$ recovery. After $\left[\mathrm{Ca}^{2+}\right]_{i}$ was increased to $120 \mathrm{nM}$, the second application of muscarine produced $127 \pm 5 \%$ recovery of $I_{\mathrm{M}}(p<0.05$ from paired $t$ test; $n=11$ ). An example is shown in Figure 8 .

\section{Alteration of $\mathrm{I}_{M}$ kinetics by calcium}

Increasing calcium slowed the deactivation of $I_{\mathrm{M}}$, while accelerating reactivation of the current (Marrion et al., 1991). The kinetics of $I_{\mathrm{M}}$ were obviously altered after raising $\left[\mathrm{Ca}^{2+}\right]_{i}$ (Fig. 9). An initial analysis was made by fitting the relaxations to single exponentials. The closing relaxation was slower at 120 $\mathrm{nM} \mathrm{Ca}{ }^{2+}$ than at $0 \mathrm{nM} \mathrm{Ca}^{2+}$. The time constant $(\tau)$ was prolonged from $109.3 \pm 14.5 \mathrm{msec}$ at $0 \mathrm{Ca}^{2+}$ to $139.2 \pm 12.1 \mathrm{msec}$ at 120 $\mathrm{nM} \mathrm{Ca}^{2+}(n=8$; Table 1$)$. On the other hand, the $\tau$ of the opening relaxation became faster at $120 \mathrm{nM} \mathrm{Ca}^{2+}$ than at $0 \mathrm{nM} \mathrm{Ca}^{2+}$, going from $216.1 \pm 18.2 \mathrm{msec}$ at $0 \mathrm{Ca}^{2+}$ to $149.1 \pm 13.9 \mathrm{msec}$ at $120 \mathrm{nM} \mathrm{Ca}^{2+}$ (Table 1, Fig. 9A,B). The kinetic changes pro- 


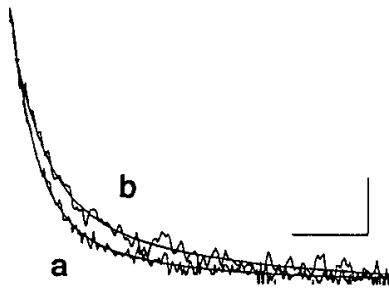

A

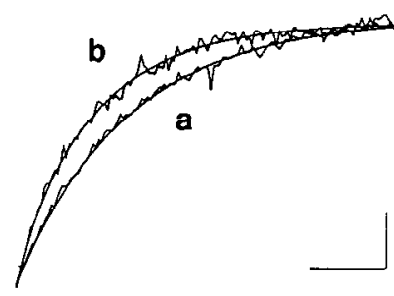

B
Figure 9. Changes in $I_{\mathrm{M}}$ kinetics at different levels of free calcium. A, Superimposed traces of closing relaxation (deactivation) recorded at 0 $\mathrm{nM} \mathrm{Ca}{ }^{2+}(a)$ and $120 \mathrm{nM} \mathrm{Ca}^{2+}(b)$. Calibration; $200 \mathrm{msec} ; 122 \mathrm{pA}(a)$, $210 \mathrm{pA}(b) . B$, The superimposed traces of reopening relaxation (reactivation) at $0 \mathrm{nM} \mathrm{Ca}^{2+}(a)$ and $120 \mathrm{nM} \mathrm{Ca}^{2+}(b)$. Calibration: $160 \mathrm{msec}$; $168 \mathrm{pA}(a), 330 \mathrm{pA}(b)$. The traces were fitted by two exponentials. For closing relaxations $\tau_{1}$ and $\tau_{2}$ were $61.7 \mathrm{msec}$ and $242.8 \mathrm{msec}$, respectively, at $0 \mathrm{nM} \mathrm{Ca}^{2+}$; after raising $\left[\mathrm{Ca}^{2+}\right]_{i}$ to $120 \mathrm{nM}, \tau_{1}$ and $\tau_{2}$ became $81.0 \mathrm{msec}$ and $379.5 \mathrm{msec}$. For reopening relaxation at $0 \mathrm{nM} \mathrm{Ca}^{2+}, \tau_{1}$ and $\tau_{2}$ were $198.0 \mathrm{msec}$ and $1272.9 \mathrm{msec}$, and the $\tau$ values were reduced

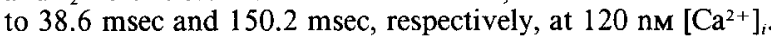

duced by lowering $\mathrm{Ca}^{2+}$ are consistent with a reduction in $\mathrm{M}$ channel open time or opening frequency, which would cause the channels to spend more time in the closed state.

As can be seen from the superimposed traces of magnified tail currents in Figure 9, a slow component appeared at the later phase of the relaxations. The relaxations hence appear to consist of two exponential components. This might reflect multiple kinetic states or different subpopulations of channels (Owen et al., 1990; Marrion et al., 1992) or perhaps nonuniform $\mathrm{Ca}^{2+}$ concentrations. We further analyzed the kinetic changes by introducing a second $\tau$ in the computer curve fitting. The fit was noticeably improved in six out of eight cells analyzed. According to the two- $\tau$ curve fitting, both fast and slow components for closing relaxation were longer at $120 \mathrm{nM} \mathrm{Ca}^{2+}$ than at $0 \mathrm{Ca}^{2+}$. The two $\tau \mathrm{s}$ for the opening relaxation both became faster in higher $\mathrm{Ca}^{3+}$ (Tablc 1). There was no sign that raising $\mathrm{Ca}^{2+}$ brought out or eliminated either of the components.

At $120 \mathrm{nM} \mathrm{Ca}^{2+}$, the time constant for the fast closing component $\left(\tau_{1}\right.$; Table 1) was $69.4 \mathrm{msec}$, consistent with a previous separate study (62.5 msec; Marrion et al., 1992). The $\tau_{2}$ for the slow component $(337.2 \mathrm{msec}$ ) was smaller than in the previous study $(573 \mathrm{msec})$. The difference might be due to the shorter voltage command ( $1 \mathrm{sec}$ vs $3 \mathrm{sec}$ ) used in this study.

These kinetic changes might be caused by activation of $\mathrm{Ca}^{2+}$ dependent $\mathrm{K}^{+}$currents, such as $I_{\mathrm{C}}$ or $I_{\mathrm{AHP}}$, by the rise in $\left[\mathrm{Ca}^{2+}\right]_{i}$. Some experiments were thus performed with TEA $(5 \mathrm{~mm})$ or d-TC $(100 \mu \mathrm{M})$ in the external superfusate to block these two currents. After perfusion with $120 \mathrm{nM} \mathrm{Ca}^{2+}$, similar kinetic changes were observed (two cells for each blocker, data not shown).

At high $\left[\mathrm{Ca}^{2+}\right]_{i}(450 \mathrm{~nm}), \tau$ values for the closing relaxation obtained from either one- or two- $\tau$ fitting (Table 1) became faster than at the lower $\mathrm{Ca}^{2+}$. The $\tau$ values obtained from two exponential fittings were even smaller than the values at zero $\mathrm{Ca}^{2+}$. This reduction in time constant was consistent with the lowered amplitude of $I_{\mathrm{M}}$ at this $\mathrm{Ca}^{2+}$ level (see Fig. $3 C$ ). Furthermore, the $\tau$ values for the opening relaxation became progressively faster as $\left[\mathrm{Ca}^{2+}\right]_{i}$ increased (Table 1).

\section{Discussion}

While it is clear that $\mathrm{M}$ current is modulated by changes in cytosolic calcium, the mechanisms subserving this modulation remain controversial. Two of the main conclusions reached here are (1) that $I_{M}$ is activated when free calcium is raised into the physiological range and (2) that $I_{\mathrm{M}}$ is inactivated when calcium is raised well above resting calcium levels. The electrophysiological aspects of this modulation are discussed, as are technical issues concerning the control and measurement of calcium levcls. A third conclusion reached is that calcium transients do not appear to be necessary for the suppression of $I_{\mathrm{M}}$ by muscarine under our experimental conditions. There is substantial disagreement concerning this third issue (Pfaffinger et al., 1988; Beech et al., 1991; Kirkwood et al., 1991; Marrion et al., 1991). The mechanisms by which $I_{\mathrm{M}}$ is regulated are discussed in this context.

\section{Establishment of calcium levels}

Intracellular perfusion is a powerful technique for modifying the internal milieu of patch-clamped nerve cells (Soejima and Noma, 1984; Lopez, 1992). The rapid change in sodium current (reversal within $5 \mathrm{~min}$ ) illustrates the effectiveness of internal perfusion. Our electrophysiological evidence indicates that free calcium levels can be modulated on the same time scale as sodium levels (Fig. 3). However, because free calcium is regulated in the nanomolar range (vs millimolar levels of free sodium), its regulation may be more powerful. To confirm the effectiveness of internal perfusion in manipulating calcium, free calcium levels were measured using the calcium indicator fluo-3.

As shown in Figure 2, large, reversible changes in fluorescence were produced by perfusing cells first with $120 \mathrm{~nm}$ free calcium, then with zero calcium solution. Based on intracellular calibration curves obtained in thesc cclls (O'Mallcy ct al., 1993), it is estimated that the greater than twofold increase in fluorescence corresponds to an increase in cytosolic free calcium of about 80-90 nм. Upon returning to zero calcium solution, the fluorescence returned to its basal level in the nucleus and to nearly

Table 1. Kinetic changes of $I_{\mathrm{M}}$ relaxations at different $\left[\mathrm{Ca}^{2+}\right]_{i}$ levels

\begin{tabular}{|c|c|c|c|c|c|c|c|}
\hline & \multicolumn{3}{|c|}{ Closing relaxation } & \multicolumn{3}{|c|}{ Opening relaxation } & \\
\hline & \multirow{2}{*}{$\begin{array}{l}\text { One- } \tau \text { fitting } \\
\tau \text { (msec) }\end{array}$} & \multicolumn{2}{|l|}{ Two- $\tau$ fitting } & \multirow{2}{*}{$\begin{array}{l}\text { One- } \tau \text { fitting } \\
\tau \text { (msec) } \\
\end{array}$} & \multicolumn{2}{|l|}{ Two- $\tau$ fitting } & \\
\hline & & $\tau_{1}(\mathrm{msec})$ & $\tau_{2}(\mathrm{msec})$ & & $\tau_{1}$ (msec) & $\tau_{2}(\mathrm{msec})$ & $n$ \\
\hline $0 \mathrm{nM} \mathrm{Ca}^{2+}$ & $109.3 \pm 14.5$ & $56.6 \pm 4.9$ & $284.0 \pm 44.7$ & $216.0 \pm 18.2$ & $118.0 \pm 39.0$ & $330.7 \pm 105$ & 8 \\
\hline $120 \mathrm{nM} \mathrm{Ca}^{2+}$ & $139.0 \pm 12.0$ & $69.4 \pm 5.5$ & $337.2 \pm 36.9$ & $149.0 \pm 13.9$ & $87.6 \pm 14.4$ & $229.9 \pm 31.4$ & 8 \\
\hline $240 \mathrm{nM} \mathrm{Ca}^{2+}$ & $206.7 \pm 22.1$ & $143.2 \pm 37.7$ & $393.9 \pm 35.9$ & $183.5 \pm 25.5$ & $98.8 \pm 24.9$ & $233.1 \pm 27.3$ & 5 \\
\hline $450 \mathrm{nM} \mathrm{Ca}^{2+}$ & $167.7 \pm 14.7$ & $49.6 \pm 8.7$ & $215.0 \pm 40.7$ & $116.4 \pm 16.8$ & $58.6 \pm 10.7$ & $439.1 \pm 136.2$ & 5 \\
\hline
\end{tabular}


its basal level in the cytoplasm. These results indicate that internal perfusion with different levels of calcium produces, at a minimum, most of the desired degree of change in free calcium. The failure of the cytoplasmic signal to fully recover is thought to be due to slow internalization of fluo-3 into organelles (O’Malley et al., 1993).

One possible reason why fluo-3 fluorescence changes in the cell were somewhat smaller than in calibration solutions is that calcium dyes behave differently in situ as compared to in droplets. Such deviations in bchavior are common with calcium indicators. Alternatively, cellular mechanisms, such as extrusion of calcium from the cytosol by ATPases and sodium/calcium exchangers, may have compensated against our dialysis. Thus, free calcium could have been a little greater than $0 \mathrm{~nm}$, and perhaps a little less than $120 \mathrm{~nm}$ during the separate stages of a typical perfusion. The key issue, however, is that fluorescence increases were large enough to indicate that most of the desired control of free calcium was observed and that $I_{\mathrm{M}}$ behaved differently in very low versus physiological/resting calcium levels.

Fluo-3 was the calcium indicator of choice because it is the most compatible with BAPTA, which is a faster buffer than the standard calcium chelator, EGTA. BAPTA also does not give off protons, as EGTA does, upon binding calcium. BAPTA is not normally used in conjunction with the ratiometric indicators fura-2 and indo- 1 because BAPTA is itself fluorescent within the excitation range of these dyes, making calibration problematic (N. V. Marrion, personal communication). With free calcium levels set by high concentrations of BAPTA, fluo-3 provides useful signals for monitoring changes in free calcium (O’Malley et al., 1993).

\section{Additional controls}

Ion channel behavior is known to be influenced by surface charge (Perozo and Bezanilla, 1990), so simple charge effects on $I_{\mathrm{M}}$ must be considered. Because the intracellular solution contained $1.5 \mathrm{~mm}$ magnesium, and because BAPTA has a high selectivity for $\mathrm{Ca}^{2+}$ over $\mathrm{Mg}^{2+}\left(>10^{5}\right.$; Tsien, 1980), the free $\mathrm{Mg}^{2+}$ concentration was orders of magnitude higher than the free calcium concentration. Free magnesium was calculated to be $222 \mu \mathrm{M}$ in zero calcium, and $252 \mu \mathrm{M}$ in $120 \mathrm{~nm}$ free calcium solutions. The change in free $\mathrm{Ca}^{2+}$ was thus only a tiny fraction $(\sim 0.03 \%)$ of free $\mathrm{Mg}^{2+}$; calcium's effect on surface charge would therefore be negligible. The $15 \%$ increase of free $\mathrm{Mg}^{2+}(30 \mu \mathrm{M})$ produced when free calcium was increased is also unlikely to cause the large changes of $I_{\mathrm{M}}$ observed.

The changes in $I_{\mathrm{M}}$ are not due to alterations of liquid junction potential, driving force, or contamination by other currents such as $I_{\mathrm{Ca}}$ or $I_{\mathrm{C}}$. The measurement of $\mathrm{M}$ current relaxation under our voltage protocol ensures that other potassium conductances do not significantly contribute to the measured $I_{\mathrm{M}}$ (Adams et al., 1982a). The use of TEA and d-TC to block potentially problematic $\mathrm{K}^{+}$currents further strengthens this identification. Effects of liquid junction potential also cannot account for the large changes observed in $I_{\mathrm{M}}$, because these potentials were carefully corrected for and any residual, uncorrected potential would not account for the substantial changes in $I_{\mathrm{M}}$.

A small inhibitory effect of BAPTA on $I_{\mathrm{M}}$, which was observed when $\left[\mathrm{Ca}^{2+}\right]_{i}$ was held constant (Fig. 1), could be due to either calcium-free or calcium-bound BAPTA. In $10 \mathrm{~mm}$ and $20 \mathrm{~mm}$ BAPTA solutions, with free calcium set at $120 \mathrm{nM}$, there would be $5.6 \mathrm{~mm}$ and $11.3 \mathrm{~mm}$ free BAPTA, respectively, while cal- cium-bound BAPTA would be 4.4 and $8.7 \mathrm{~mm}$, respectively. These effects of BAPTA were tested at $120 \mathrm{nM}\left[\mathrm{Ca}^{2+}\right]_{i}$, where small fluctuations in free calcium would not greatly affect $I_{\mathrm{M}}$ (Fig. 3C). Efforts to carefully control free calcium levels, for example, use of a single batch (i.e., purity) of BAPTA, should have minimized any deviations in free calcium. It should be noted that these effects of BAPTA were quite small $(20 \%$ inhibition) in relation to the much larger effects occurring when free calcium was changed (up to $80 \%$ inhibition), so the effects observed upon perfusion of different levels of free calcium are not due to changes in BAPTA. This was confirmed in the experiments where free BAPTA was held constant and calcium was increased from 0 to $120 \mathrm{nM}$ : the typical increases in $I_{\mathrm{M}}$ were observed.

Good dialysis of the cell was necessary to manipulate effectively intracellular $\mathrm{Ca}^{2+}$. With a longer shank electrode and higher tip resistance ( $>5 \mathrm{M} \Omega$ ), large $I_{\mathrm{M}}$ persisted even in nominally zero calcium solution. But with our typical low-resistance electrodes, in the low calcium range, changes of a few tens of nanomolars dramatically altered $I_{M}$ (Fig. $3 C$ ). Since electrode geometry strongly affects the time constant of diffusion and dialysis (Oliva et al., 1988), it seems likely, with high-resistance electrodes, that calcium levels were not well controlled. This is consistent with our observation that changes in calcium were somewhat slower with the $3 \mathrm{M} \Omega$ electrodes used for calcium imaging.

\section{Effects of calcium on $M$ current}

The alteration of $I_{\mathrm{M}}$ by changes in free calcium are reversible and reproducible. At the lower limit of physiological calcium levels, small increases in $\left[\mathrm{Ca}^{2+}\right]_{i}$ will strongly enhance $I_{\mathrm{M}}$, while small decreases will reduce it. When $\left[\mathrm{Ca}^{2+}\right]_{i}$ is raised well above resting calcium levels, $I_{\mathrm{M}}$ is again reduced, but not to nearly the same extent. This is qualitatively consistent with the results of Marrion et al. (1991), who showed that step increases in calcium, produced by photolysis of nitr-5, a photoreleased calcium chelator, caused $I_{\mathrm{M}}$ to increase at low levels of free calcium and decrease at higher levels. As also reported here, these were sustained effects. Thus, it is the absolute level of $\left[\mathrm{Ca}^{2+}\right]_{i}$, not the nanomolar increase, which determines the size of $I_{\mathrm{M}}$. The increase of $\mathrm{M}$ conductance by calcium is accompanied by a negative shift of the half-activation voltage. Thus, at a given voltage, a greater fraction of the available $g_{M}$ will be active following stimulation. A similar shift in $V_{\text {half }}$ was found in gastric smooth muscle cells for modulation of $I_{\mathrm{M}}$ by a $\beta$-adrenergic agent and cAMP analogs (Sims et al., 1990). Also, calcium appears to regulate $M$ channels whether they are open or closed. This was shown by switching from $0 \mathrm{nM}$ to $120 \mathrm{nM}$ calcium while holding most of the channels closed at a holding potential of $-60 \mathrm{mV}$. However, at $-60 \mathrm{mV}$ a small fraction of $\mathrm{M}$ channels might still be open, so it remains possible that the channels were modulated by calcium while in the open state.

Modulation of $I_{M}$ by calcium involves changes in channel kinetics. Calcium accelerates opening of $\mathrm{M}$ channels and shows a biphasic action on channel closing rate, depending on its concentration. The kinetic analysis suggests that the secondary inhibition of $I_{M}$ in high $\mathrm{Ca}^{2+}(450 \mathrm{nM})$ is due to facilitation of the channel "off" rate rather than a decrease in open probability. This indicates that although $I_{\mathrm{M}}$ appears smaller either in very low or high calcium, the underlying mechanisms may not be the same. High calcium, for example, $450 \mathrm{~nm}$, stimulates acti- 
vation as well as deactivation of $\mathrm{M}$ channels. High calcium may push M channels to a "new" gating state in which the channels exhibit accelerated opening and closing rates (see, e.g., Marrion, 1993). Because the potassium channel blockers TEA and d-TC were not used at the high calcium levels, it is possible that other potassium currents may have contaminated the opening relaxation, but the closing relaxation would still be essentially pure M current.

Calcium is also involved in the muscarinic suppression of $I_{\mathrm{M}}$. $M$ current was more suppressible at resting calcium levels than in low calcium. This suggests that the muscarinic suppression pathway has calcium-dependent steps, but an alternative possibility is that there may be a fraction of $M$ channels that are insensitive to muscarine. Thus, the greater suppression observed in $120 \mathrm{~nm}$ calcium, versus zero calcium, may be due simply to the possibility that in zero calcium, the muscarine-insensitive channels constituted a larger fraction of the total $M$ current. This, however, does not explain the increase in $I_{\mathrm{M}}$ observed during muscarinic suppression when calcium is lowered to $0 \mathrm{nM}$ (Fig. 7). Normally, this would suppress $I_{M}$; the substantial increase that occurs suggests that calcium indeed plays a role in sustaining muscarinic suppression.

Calcium may also play a role in the overrecovery of $I_{\mathrm{M}}$ that occurs when muscarine is removed. A residual elevation of calcium, induced by application of muscarine, was proposed to activate $M$ channels. This activation would then be unveiled upon removal of muscarine (Marrion et al., 1991). In our experiments, however, overrecovery occurs while calcium is apparently held close to its resting level by the $20 \mathrm{~mm}$ BAPTA present (see discussion below). Also, our resting level of calcium should maximally activate $I_{\mathrm{M}}$ (Fig. $3 C$ ) and so a residual increase present after muscarine removal should not further activate it. Our data do suggest that free calcium is involved in overrecovery, but in a different way. We find that overrecovery occurs at $120 \mathrm{~nm}$ calcium but not at zero calcium (Fig. 8). This again suggests that a sustained level of free calcium is important for the functioning of the regulatory pathway, in this case for the pathway that allows $I_{\mathrm{M}}$ to exceed the level present before application of muscarine.

Our data argue against a role for extracellular calcium in modulating $I_{\mathrm{M}}$. Tokimasa and Akasu (1990a) reported reduction of $I_{\mathrm{M}}$ by an external $\mathrm{Ca}^{2+}$-free solution that depressed the maximum $\mathrm{M}$ conductance. They proposed that calcium binding sites on the outside of the membrane may be affiliated with $\mathrm{M}$ channels. Our results show, however, that with intracellular calcium tightly controlled by BAPTA, changing extracellular calcium had minimal effects on $I_{\mathrm{M}}$. Calcium imaging showed that changing extracellular calcium had minuscule effects on intracellular calcium when $20 \mathrm{~mm}$ BAPTA was present, consistent with the lack of effect on $M$ current.

\section{Is there a role for calcium transients in muscarinic suppression of $\mathrm{I}_{M}$ ?}

The study by Kirkwood et al. (1991) provides the strongest argument that calcium transients are an element of the signaling pathway through which muscarine inhibits $I_{\mathrm{M}}$. The essential finding of that report is that muscarine can suppress $I_{\mathrm{M}}$ in cells loaded with $0.3 \mathrm{~mm}$ BAPTA, but perfusing these same cells with 20 mм BAPTA strongly diminishes the muscarinic suppression. Thus, the elimination of the muscarine-induced calcium transient, by $20 \mathrm{~mm}$ BAPTA, is proposed to uncouple activation of the receptor from the modulatory pathway. In contrast, earlier reports showed that when calcium transients were prevented by a similarly high level of calcium chelator, muscarinic suppression proceeded as usual (Pfaffinger et al., 1988; Beech et al., 1991; Marrion et al., 1991). Two distinct issues must be resolved to evaluate the role of calcium transients. The first issue is whether muscarine is truly capable of suppressing $I_{\mathrm{M}}$ in the presence of $20 \mathrm{~mm}$ BAPTA. A second, distinct, issue is whether powerful buffering by 20 m $\mathrm{mAPTA}$ can truly suppress calcium transients.

Kirkwood et al. (1991) suggest that higher dosages of muscarine might account for the conflicting results. However, we observe a $70 \%$ inhibition of $I_{\mathrm{M}}$ with as little as $1 \mu \mathrm{M}$ muscarine. A related issue is the duration of application of muscarine. A long application of muscarine might produce a longer release of calcium that could overwhelm the buffering capacity of $20 \mathrm{~mm}$ BAPTA. However, Figure 7 shows that muscarinic inhibition reaches a maximum in less than $15 \mathrm{sec}$, so any later relcasc of calcium is probably irrelevant. In agreement with this, Marrion et al. (1991, Fig. 3) show that the time course of muscarinic suppression is the same in $20 \mathrm{~mm}$ BAPTA or in $0.1 \mathrm{~mm}$ EGTA. It should take substantially longer for muscarine to overwhelm the buffer in $20 \mathrm{~mm}$ BAPTA.

This agrees with previous studies reporting that $20 \mathrm{~mm}$ BAPTA is insufficient to block the muscarinic effect (Beech et al., 1991; Marrion et al., 1991). In contrast, in the Kirkwood study, the time course of inhibition is substantially slowed by $20 \mathrm{~mm}$ BAPTA, so the different results are not readily reconciled. By our calculations, the intracellular formula used in Kirkwood et al.'s 20 mM BAPTA solution should have set free calcium at a level of about $100 \mathrm{nM}$, a level well into the range where $I_{\mathrm{M}}$ should be highly suppressible. Kirkwood et al.'s data could be explained if for some unknown reason perfusion with $20 \mathrm{~mm}$ BAPTA lowered resting free calcium in their experiments.

Marrion et al. (1991) report that $10 \mu \mathrm{M}$ muscarine induces a $50 \mathrm{nM}$ increase in free calcium in cells loaded with only $0.2 \mathrm{~mm}$ buffer (100 $\mu_{\mathbf{M}}$ fura 2, $100 \mu \mathrm{M}$ EGTA). We have measured calcium transients in voltage-clamp experiments, where calcium influx is controlled via voltage-gated calcium currents (O'Malley et al., 1993; D. M. O’Malley, unpublished observations). In those experiments, highly localized, bricf transients were routinely measured in low concentrations of calcium buffer $(100$ $\mu \mathbf{M}$ fluo-3). Inclusion of $10 \mathrm{mM}$ BAPTA, however, completely prevented the appearance of transients during an extremely rapid influx of calcium (50 $\mathrm{msec}$ depolarizations) that would have raised calcium to micromolar levels near the membrane. Given then that muscarine produces only a small, relatively slow increase in low buffer, it seems likely that 20 mM BAPTA strongly inhibited the size and spread of muscarine-induced calcium transients. This agrees with the results of Beech et al. (1991), who showed that the normally large increase in free calcium induced by $10 \mathrm{~mm}$ caffeine was completely buffered by $20 \mathrm{~mm}$ BAPTA (also see Marrion and Adams, 1992).

This type of experiment cannot rule out, however, highly localized actions of calcium occurring between calcium release channels and calcium binding molecules (e.g., protein kinase $\mathrm{C}$ ) that might be situated adjacent to one another and to the $M$ channels. Thus, a role for calcium transients in the muscarinic suppression pathway is still an open issue. An alternative explanation, one that we favor, is that muscarine induces prolonged production of a second messenger other than calcium and that removal of muscarine allows this messenger to decline quickly. 


\section{Mechanism of regulation of $\mathrm{I}_{M}$ by calcium}

I ow levels of free calcium clearly reduce $I_{\mathrm{M}}$. This observation could result from a direct action of calcium on the $\mathrm{M}$ channel or on any affiliated molecules that affect channel gating; resting calcium levels would therefore be necessary for normal functioning. A more complex form of inhibition is suggested, however, by the observation that ATP is required to restore $M$ current to normal levels when calcium is raised from $0 \mathrm{nM}$ to $120 \mathrm{nM}$ (Fig. 5). Since most of the restoration depended on ATP (see also Tokimasa and Akasu, 1990b), this suggests that a phosphorylation event is involved in the regulation of $I_{\mathrm{M}}$ by absolute calcium levels. A simple explanation is that phosphorylation of the $M$ channel at resting calcium levels, by a calcium-dependent enzyme, maintains a resting level of $I_{\mathrm{M}}$ activation. In low calcium, the channel then becomes dephosphorylated, and cannot be reactivated in the absence of ATP. Onc candidate for a role in reactivation of $I_{\mathrm{M}}$ is calmodulin (reviewed by Walaas and Greengard, 1991). Increasing calcium from 0 nM to $120 \mathrm{~nm}$ could potentially stimulate calmodulin and activate calmodulin-dependent protein kinases. Preliminary experiments showed that a calmodulin antagonist W-7 $(20 \mu \mathrm{M} ; n=3)$ failed to influence the enhancement of $I_{M}$ by calcium (data not shown), but firm conclusions should not be drawn from this.

At high calcium levels, $I_{M}$ is again inhibited. Because this modulation is kinetically different than the modulation by low calcium, a different mechanism is likely to be involved. The observation that high levels of calcium ( $450 \mathrm{~nm}$ ) do not suppress $M$ current to nearly the same extent as zero calcium further suggests an independent mechanism. The reduction of $I_{\mathrm{M}}$ at high calcium could be due to a direct action of calcium on the channel, since the effects of ATP were not evaluated at this calcium level. These high calcium levels are likely to occur during physiological stimulation (Llinas et al., 1992). It is less certain whether or not the low calcium levels required for reduction of $I_{\mathrm{M}}$ occur naturally, although some groups report resting levels of 30-50 nм (Nohmi et al., 1988; Pfaffinger et al., 1988; Bosma et al., 1990). In summary, calcium increases may either up- or downregulate $I_{\mathrm{M}}$, depending on resting levels of free calcium.

Another candidate system considered for the modulation of $M$ current is protein kinase $\mathrm{C}$ (PKC). Activation of protein kinase $\mathrm{C}$ by phorbol esters partially suppresses $I_{\mathrm{M}}$ (Brown and Adams, 1987; Bosma and Hille, 1989). The activation of PKC is $\mathrm{Ca}^{2+}$ dependent (reviewed by Huang, 1989) which is consistent with the inhibition of $I_{\mathrm{M}}$ at high levels of calcium (Fig. 3; Marrion et al., 1991). PKC was also considered to be a candidate for mediating the suppression of $I_{\mathrm{M}}$ by muscarine and LHRH. While evidence is accumulating against this possibility (Bosma and Hille, 1989; Tokimasu and Akasu, 1990b; Marrion, personal communication), the involvement of other protein kinases in muscarinic suppression remains an open issue.

The role of calcium in muscarinic suppression of $I_{\mathrm{M}}$ appears both complex and controversial. While our experiments do not indicate a direct role for calcium transients in muscarinic suppression, single-channel recording experiments do suggest that suppression is mediated by an unknown cytoplasmic signal (Marrion, 1993). One explanation is that there are calciumdependent steps in this regulatory pathway. At resting calcium, muscarinic suppression proceeds swiftly. But in zero calcium, this pathway cannot proceed efficiently, and the muscarinic suppression of $I_{\mathrm{M}}$ is incomplete (Fig. 7). Because suppression of $I_{\mathrm{M}}$ by low calcium and by muscarine are distinct from each other, there may be multiple sites on the $\mathbf{M}$ channel or associated structures that are independently regulated. An intriguing possibility, based on the observation that the $M$ channels exists in distinct gating modes, is that only one mode is sensitive to muscarine (Marrion, 1993).

One candidate that appears to play a role in muscarinic modulation of $I_{\mathrm{M}}$ is arachidonic acid (AA), which together with its metabolites in hippocampal CAl pyramidal neurons may mediate somatostatin augmentation of $I_{M}$ (Schweitzer et al., 1990). Arachidonic acid liberation by phospholipase $A_{2}$ is known to be calcium dependent (Ballou and Cheung, 1985; Clark et al., 1991). Also, purified phospholipase $A_{2}$ from rat kidney is activated at physiological calcium concentrations (Gronich et al. 1990). The activation of several metabolic enzymes in the AA pathway requires both calcium and ATP (Vonakis and Vanderhoek, 1989; Dragan and Ellis, 1990; Wong et al., 1991). In bullfrog sympathetic neurons, AA increased $I_{\mathrm{M}}$ (Bosma et al., 1990). Work in our lab shows that AA and specific metabolites are involved in the modulation of $I_{\mathrm{M}}$ ( $\mathrm{Yu}$ and Adams, 1991, 1992). Recent work suggests that distinct branches of the AA metabolic pathway subserve the modulation of this widespread channel (S. P. Yu and P. R. Adams, unpublished observations).

\section{References}

Adams PR, Brown DA (1982) Synaptic inhibition of the M-current slow excitatory post-synaptic potential mechanism in bullfrog sympathetic neurones. J Physiol (Lond) 332:263-272.

Adams PR, Brown DA, Constanti A (1982a) M-currents and other potassium currents in bullfrog sympathetic neurones. J Physiol (Lond) 330:537-572.

Adams PR, Brown DA, Constanti AA (1982b) Pharmacological inhibition of the M-current. J Physiol (Lond) 332:223-262.

Akaike N, Sadoshima J (1989) Caffeine affects four different ionic currents in the bull-frog sympathetic neurone. J Physiol (Lond) 412: 221-244.

Ballou LR, Cheung WY (1985) The role of calcium in prostaglandin and thromboxane biosynthesis. In: Calcium and cell physiology (Marmé D, ed), pp 285-297. Berlin: Springer.

Beech DJ, Bernheim L, Mathie A, Hille B (1991) Intracellular $\mathrm{Ca}^{2+}$ buffers disrupt muscarinic suppression of $\mathrm{Ca}^{2+}$ current and $\mathrm{M}$ current in rat sympathetic neurons. Proc Natl Acad Sci USA 88:625-656.

Bosma MM, Hille B (1989) Protein kinase C is not necessary for pcptide-induced suppression of $\mathrm{M}$ current or for desensitization of the peptide receptors. Proc Natl Acad Sci USA 86:2943-2947.

Bosma MM, Bernheim L, Leibowitz MD, Pfaffinger PJ, Hille B (1990) Modulation of $M$ current in frog sympathetic ganglion cells. In: $\bar{G}$ proteins and signal transduction (Nathanson NM, Harden TK, eds), pp 43-59. New York: Rockefeller UP.

Brown DA (1988) M-currents. In: Ion channels, Vol 1 (Narahashi T, ed), pp 55-94. New York: Plenum.

Brown DA, Adams PR (1980) Muscarinic suppression of a novel voltage-sensitive $\mathrm{K}^{+}$current in a vertebrate neurone. Nature 283 . 673-676.

Brown DA, Adams PR (1987) Effects of phorbol dibutyrate on M-currents and $\mathrm{M}$-current inhibition in bullfrog sympathetic neurons. Cell Mol Neurobiol 7:255-269.

Brown DA, Higashida H (1988) Inositol 1,4,5-trisphosphate and diacylglycerol mimic bradykinin effects on mouse neuroblastoma rat glioma hybrid cells. J Physiol (Lond) 397:185-207.

Clark JD, Lin LL, Kriz RW, Ramesha CS, Sultzman LA, Lin AY, Milona N, Knopf JL (1991) A novel arachidonic acid-selective cytosolic $\mathrm{PLA}_{2}$ contains a $\mathrm{Ca}^{2+}$-dependent translocation domain with homology to PKC and GAP. Cell 65:1043-1051.

Dragan YP, Ellis EF (1990) Effect of adenine nucleotides on cyclooxygenase and lipoxygenase enzyme products of arachidonic acid in human platelets. Biochem Pharmacol 39:27-32.

Dutar P, Nicoll RA (1988) Stimulation of phosphatidylinositol (PI) turnover may mediate the muscarinic suppression of the M-current in hippocampal pyramidal cells. Neurosci Lett 85:89-94.

Fabiato A (1988) Computer programs for calculating total from spec- 
ified free or free from specified total ionic concentrations in aqueous solutions containing multiple metals and ligands. Methods Enzymol 157:378-417.

Goh JW, Pennefather PS (1987) Pharmacological and physiological properties of the after-hyperpolarization current of bullfrog ganglion neurones. J Physiol (Lond) 394:315-330.

Gronich JH, Bonventre JV, Nemenoff RA (1990) Purification of a high-molecular-mass form of phospholipase $\mathrm{A}_{2}$ from rat kidney activated at physiological calcium concentrations. Biochem J 271:3743.

Hamill O, Marty A, Neher E, Sakmann B, Sigworth FJ (1981) Improved patch-clamp techniques for high-resolution current recording from cells and cell-free membrane patches. Pfluegers Arch 391:85100.

Harrison SM, Bers DM (1987) The effect of temperature and ionic strength on the apparent Ca-affinity of EGTA and the analogous Cacheiators BAPTA and dibromo-BAPTA. Biochim Biophys Acta 925: 133-143.

Higashida H, Brown DA (1986) Two phosphatidylinositide metabolites control two $\mathrm{K}^{+}$currents in a neuronal cell. Nature 323:333-335.

Huang K-P (1989) The mechanism of protein kinase C activation. Trends Neurosci 12:425-432.

Jones SW (1987) Sodium currents in dissociated bull-frog sympathetic neurones. J Physiol (Lond) 389:605-627.

Kao IPY, Harootunian AT, Tsien RY (1989) Photochemically generated cytosolic calcium pulses and their detection by fluo-3. J Biol Chem 264:8179-8184.

Kirkwood A, Simmons MA, Mather RJ, Lisman J (1991) Muscarinic suppression of the M-current is mediated by a rise in internal $\mathrm{Ca}^{2+}$ concentration. Neuron 6:1009-1014.

Koketsu K, Akasu T, Miyagawa M (1982) Identification of $\mathrm{g}_{\mathrm{K}}$ systems activated by $\left[\mathrm{Ca}^{2+}\right]$. Brain Res 243:369-372.

Kuffler SW, Sejnowski TJ (1983) Peptidergic and muscarinic excitation at amphibian sympathetic synapses. J Physiol (Lond) 341:257278.

Llinas R, Sugimori M, Silver RB (1992) Microdomains of high calcium concentration in a presynaptic terminal. Science 256:677-679.

Lopez HS (1992) Kinetics of G protein-mediated modulation of the potassium M-current in bullfrog sympathetic neurons. Neuron 8:725736.

Marrion NV (1993) Selective reduction of one mode of M-channel gating by muscarine in sympathetic neurons. Neuron 11:77-84.

Marrion NV, Adams PR (1992) Release of intracellular calcium and modulation of membrane currents by caffeine in bull-frog sympathetic neurones. J Physiol (Lond) 445:515-535.

Marrion NV, Smart TG, Marsh SJ, Brown DA (1989) Muscarinic suppression of the $\mathrm{M}$-current in the rat sympathetic ganglion is mediated by receptors of the $\mathrm{M}_{1}$-subtype. Br J Pharmacol 98:557-573.

Marrion NV, Zucker RS, Marsh SJ, Adams PR (1991) Modulation of M-current by intracellular $\mathrm{Ca}^{2+}$. Neuron 6:533-545.

Marrion NV, Adams PR, Gruner W (1992) Multiple kinetic states underlying macroscopic M-currents in bullfrog sympathetic neurons. Proc R Soc Lond [Biol] 248:207-214.

Nohmi M, Kuba K, Ogura A, Kudo Y (1988) Measurement of intracellular $\mathrm{Ca}^{2+}$ in the bullfrog sympathetic ganglion cells using fura-2 fluorescence. Brain Res 438:175-181.

Oliva C, Cohen IS, Mathias RT (1988) Calculation of time constants for intracellular diffusion in whole cell patch clamp configuration. Biophys J 54:791-799.
O'Malley DM, Yu SP, Burbach BJ, Adams PR (1993) Evidence against persistent nuclear/cytosolic calcium gradients in bullfrog sympathetic neurons. Soc Neurosci Abstr 19:1113.

Owen DG, Marsh SJ, Brown DA (1990) M-current noise and putative M-channels in cultured rat sympathetic ganglion cells. J Physiol (Lond) 431:269-290.

Pennefather P, Lancaster B, Adams PR, Nicoll RA (1985) Two distinct Ca-dependent K currents in Bullfrog sympathetic ganglion cells. Proc Natl Acad Sci USA 82:3040-3044.

Perozo E, Bezanilla R (1990) Phosphorylation affects voltage gating of the delayed rectifier $\mathrm{K}^{+}$channel by electrostatic interactions. Neuron 5:685-690.

Pfaffinger PJ (1988) Muscarine and t-LHRH suppress M-current by activating an IAP-insensitive $G$ protein. J Neurosci 8:3343-3353.

Pfaffinger PJ, Leibowitz MD, Subers EM, Nathanson NM, Almers W, Hille B (1988) Agonists that suppress M-current elicit phosphoinositide turnover and $\mathrm{Ca}^{2+}$ transients, but thesc do not explain M-current suppression. Neuron 1:477-484.

Schweitzer P, Madamba S, Siggins GR (1990) Arachidonic acid metabolites as mediators of somatostatin-induced increase of neuronal M-current. Nature 346:464-467.

Sims SM, Clapp LH, Walsh JV Jr, Singer JJ (1990) Dual regulation of $M$ current in gastric smooth muscle cells: $\beta$-adrenergic-muscarinic antagonism. Pfluegers Arch 417:291-302.

Soejima M, Noma A (1984) Mode of regulation of the ACh-sensitive $\mathrm{K}$-channel by the muscarinic receptor in rabbit atrial cells. Pfluegers Arch 400:424-431.

Tokimasa $\mathrm{T}$ (1985) Intracellular $\mathrm{Ca}^{2+}$-ions inactivate $\mathrm{K}^{+}$-current in bullfrog sympathetic neurons. Brain Res 337:386-391.

Tokimasa T, Akasu T (1990a) Extracellular calcium ions are required for muscarine-sensitive potassium current in bullfrog sympathetic neurons. J Auton Nerv Syst 29:163-174.

Tokimasa T, Akasu T (1990b) ATP regulates muscarine-sensitive potassium current in dissociated bull-frog primary afferent neurones. $J$ Physiol (Lond) 426:241-264.

Tsien RY (1980) New calcium indicators and buffers with high selectivity against magnesium and protons: design, synthesis, and properties of prototype structures. Biochemistry 19:2396-2404.

Vonakis BM, Vanderhoek JY (1989) Role of calcium in the regulation of mammalian lipoxygenases. In: Cell calcium metabolism, physiology, biochemistry, pharmacology, and clinical implications (Fiskum G, ed), pp 387-396. New York: Plenum.

Walaas AI, Greengard P (1991) Protein phosphorylation and neuronal function. Pharmacol Rev 43:299-349.

Wong A, Cook MN, Foley JJ, Sarau HM, Marshall P, Hwang SM (1991) Influx of extracellular calcium is required for the membrane translocation of 5-lipoxygenase and leukotriene synthesis. Biochemistry 30:9346-9354.

Yu SP, Adams PR (1991) Effect of arachidonic acid pathway inhibitors on calcium regulated $M$ current enhancement. Soc Neurosci Abstr 17:67.

Yu SP, Adams PR (1992) M channel modulation by muscarine is affected by intracellular free $\mathrm{Ca}^{2+}$ and a lipoxygenase inhibitor. Soc Neurosci Abstr 18:795.

Yu SP, Marrion NV, Villarroel A, Adams PR (1991) Effects of intracellular calcium on $\mathbf{M}$ current revealed by intracellular perfusion. Biophys J 59:78a. 